\title{
Application of Processing and Packaging Hurdles for Fresh-Cut Fruits and Vegetables Preservation
}

\author{
Maria C. Giannakourou ${ }^{1}$ (D) and Theofania N. Tsironi ${ }^{2, *(D)}$ \\ 1 Laboratory of Chemistry, Analysis \& Design of Food Processes, Department of Food Science and Technology, \\ School of Food Sciences, University of West Attica, Agiou Spyridonos, 12243 Athens, Greece; \\ mgian@uniwa.gr \\ 2 Laboratory of Food Process Engineering, Department of Food Science and Human Nutrition, Agricultural \\ University of Athens, Iera Odos 75, 11855 Athens, Greece \\ * Correspondence: ftsironi@aua.gr; Tel.: +30-210-529-4703
}

Citation: Giannakourou, M.C.;

Tsironi, T.N. Application of

Processing and Packaging Hurdles for Fresh-Cut Fruits and Vegetables Preservation. Foods 2021, 10, 830. https://doi.org/10.3390/ foods10040830

Academic Editor: Alejandro Castillo

Received: 9 March 2021

Accepted: 9 April 2021

Published: 11 April 2021

Publisher's Note: MDPI stays neutral with regard to jurisdictional claims in published maps and institutional affiliations.

Copyright: (c) 2021 by the authors. Licensee MDPI, Basel, Switzerland. This article is an open access article distributed under the terms and conditions of the Creative Commons Attribution (CC BY) license (https:// creativecommons.org/licenses/by/ $4.0 /)$.

\begin{abstract}
Recently, consumers' demand for fresh, nutritious, and convenient food has shown a significant rise. This trend has forced increased sales of minimally processed and/or pre-packed fruitand vegetable-based products. New product development and the diversification of plant-based foods have supported this growth. The food production sector should balance this requirement with the necessity to provide safe food with extended shelf life while meeting consumer demands for novel, nutritious, and affordable food products. The use of alternative "soft hurdles" may result in a decrease in the rate of food deterioration and spoilage attributed to microbial activity or other physiological/chemical degradation reactions. The objective of the article is to provide a systematic review of the preservative effect of the available hurdles implemented during processing and packaging of fresh-cut fruits and vegetables, focusing on recent applications aiming at improving product quality and prolonging their limited shelf life.
\end{abstract}

Keywords: plant-based foods; hurdles; quality; preservation; processing; packaging

\section{Introduction}

Fruits and vegetables play a significant role in healthy human nutrition and possess a high ranking on the list of consumer priorities. The World Health Organization suggested a $400 \mathrm{~g}$ daily consumption of fruits and vegetables [1]. In response to this recommendation, several programs relevant to food and health (for example, five-a-day) have been carried out in order to encourage the consumption of fruits and vegetables during the 1990s and later on $[2,3]$. Despite the indisputable health benefits and convenience, quality preservation, shelf-life extension, and microbial safety assurance of such perishable foods are essentially important. It is well established that postharvest physiological modifications and the potential bacterial contaminations occurring during preharvest and postharvest handling, as well as the additional production steps (e.g., peeling, cutting, slicing, or shredding), cause rapid deterioration and spoilage of fruits and vegetables [4,5]. Several significant foodborne outbreaks have been associated with the consumption of ready-to-eat, fresh, or minimally processed fruits and vegetables, and the numbers of reported cases have shown a constant rise during the past two decades [6].

Several food preservation methods have been applied with the aim to inhibit the growth of microorganisms and preserve the quality of fruits and vegetables. Most processing technologies are based on a single preservation factor (e.g., high temperatures, chill storage, water activity decrease, etc.), which frequently alters the initial quality food profile, especially in terms of sensory, nutritional, and physicochemical properties. However, each one of the preservation techniques presents an optimum to minimum level that influences microorganisms per se. 
New trends for the production of food products according to consumer demands are minimally or not at all preserved, possessing higher quality, more "natural" sensory properties, produced with or without additives, microbiologically safe and nutritional healthier [7]. The hurdle technology introduces the combined application of conventional and innovative preservation methods, intending to provide a series of preservative factors (hurdles) that microorganisms cannot overcome. Food preservation implies putting microorganisms in a hostile environment to inhibit their growth or shorten their survival or cause their death. The feasible responses of microorganisms to this hostile environment determine whether they may grow or die. In essence, the hurdle approach targets the physiological aspects of microorganisms, and this process involves four major mechanisms: homeostasis, metabolic exhaustion or auto-sterilization, stress reaction, or multitarget preservation of foods [8-10]. Aiming to achieve the target of microbial stability, multiple hurdles (appropriate set of applied barriers) are combined to retain the initial superior nutritional and sensory qualities of food. The most important hurdles used in food preservation are the temperature during processing, transportation, and storage (high or low), water activity $\left(\mathrm{a}_{\mathrm{w}}\right)$, acidity $(\mathrm{pH})$, redox potential (Eh), preservatives (e.g., natural or synthetic), and competitive microorganisms (e.g., lactic acid bacteria) [8,9]. According to Leistner [8,9], more than 60 potential hurdles have been reported for foods, which may enhance the stability and quality of food products; however, this list is by any means not yet complete. The individual hurdles may be applied concurrently or sequentially, depending on the means of hurdle used and the preservation method of the product [10]. The application of this approach (reported as well as combined processes or barrier technology) has shown its potential as very effective on a wide range of food product types [10,11], as the intelligent combination of hurdles may secure the microbial safety and quality as well as the organoleptic parameters, nutritional value and economic feasibility of a product. This may result in a dramatically different product with unique, new appearance and taste properties. The most important factor for the successful application of hurdle technology is the selection of appropriate hurdles for the target food product. In this context, the purpose of this review article is to summarize the main degradation modes of fresh-cut fruits and vegetables and critically describe the available hurdles implemented during their processing and packaging, focusing on recent applications.

\section{Principal Modes of Deterioration of Fresh-Cut Fruits and Vegetables}

Fruits and vegetables are living food products successively undergoing a ripening and an ageing process, where the plant tissue is actually broken down. The plant-based products undergo various biological processes, which continue long after the harvesting time, such as the respiration process and the ethylene production, which occur at different rates between different fruits and vegetables [12]. The effect of respiration on the quality of fresh produce may include weight loss as a result of oxidative breakdown of substrate molecules-for example, starch, sugars, and organic acids to simpler molecules (e.g., $\mathrm{CO}_{2}$ and $\mathrm{H}_{2} \mathrm{O}$ ) [13]. As far as fresh-cut fruits and vegetables are concerned, spoilage is often attributed to physiological and microbiological processes and their interactions [14]. An indicative flow chart of such products manufacture, including a variety of treatments prior to the application of "hurdle technology," is shown in Figure 1 [15]. 


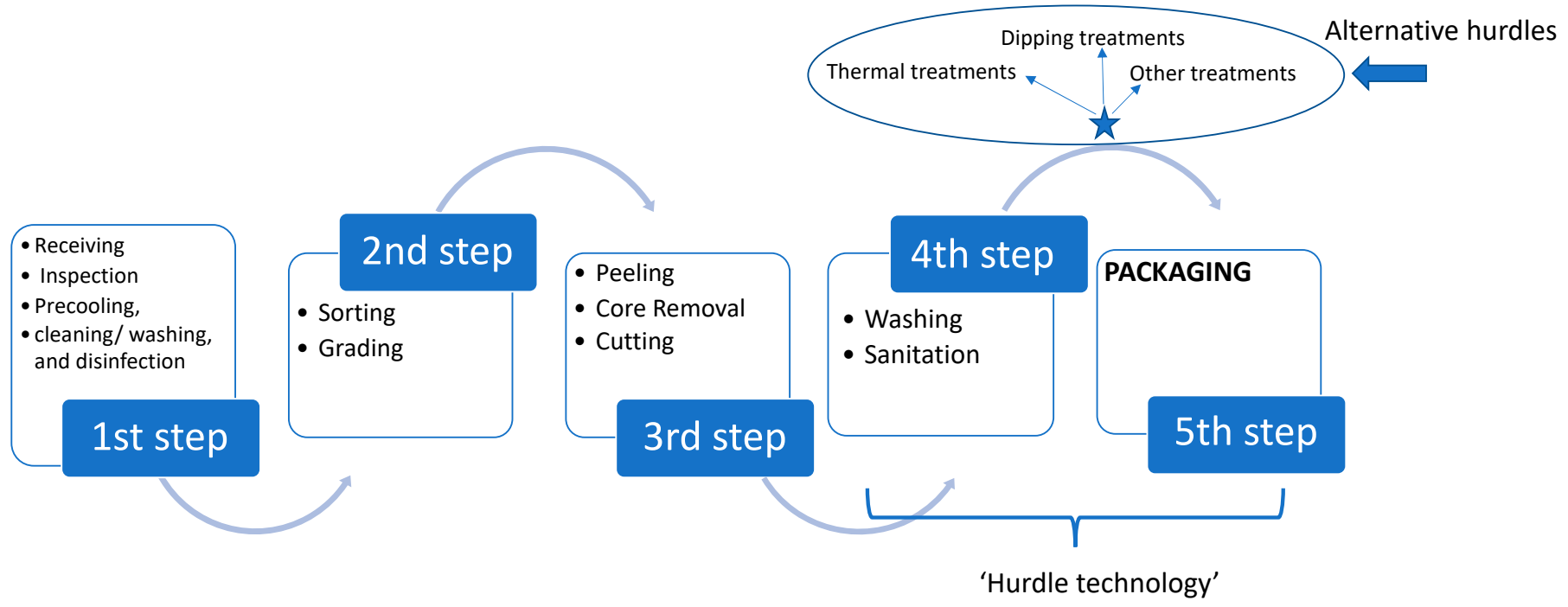

Figure 1. Indicative flow chart of fresh-cut fruits and vegetables' manufacturing process.

In this section, the most important quality characteristics and the main deterioration modes of these perishable plant tissues will be briefly outlined, with the purpose to better demonstrate the necessity of specific barriers/packaging approaches for their preservation. It is not in the scope of this review article to describe the modes of deterioration of such perishable tissues in detail, an issue that is explicitly presented in [16-18].

\subsection{Microbial Spoilage}

As detailed in [16,17], since fruits and vegetables constitute good sources of nutrients and water, a variety of microorganisms could potentially grow under ambient conditions. A microbial attack can take place either in the field or during postharvest and processing operations. Spoilage bacteria include species such as Pseudomonadaceae, Enterobacteriaceae, and other species within lactic acid bacteria (mainly Leuconostoc mesenteroides). Depending on the composition of the plant matrix, many different yeast and mold species have been identified in fresh-cut fruits and vegetables. In most cases, however, the presence and proliferation of these microorganisms affect severely product quality but do not actually jeopardize consumers' health. Focusing on pathogens, only a few species have been found in fresh-cut produce, such as Escherichia coli O157:H7, Salmonella spp., Shigella spp., Listeria monocytogenes, Campylobacter, and certain viruses and parasites. There are numerous published investigations that have explicitly described the effect of several treatments on the microbiological decay of a variety of horticultural products, e.g., in carrot [19], cantaloupe [20-22], apple wedges [23], strawberries [24], etc.

\subsection{Physiological Activity}

Fresh-cut produce requires wounding the plant tissue, which frequently initiates a sequence of respiratory, metabolic, and enzymatic activities that result in important quality degradation [18]: texture deterioration, enhanced ripening and senescence, formation of unpleasant off-flavors, degradation of color, and other undesirable changes. All these reactions occurring in fresh-cut fruit and vegetable products decrease product shelf life significantly and, consequently, can render the product unmarketable. Postharvest behavior of climacteric tissues is characterized by increased respiration, accelerated ethylene-a gaseous ripening plant hormone-production, and several other composite metabolic activities that may trigger ripening and senescence of such vulnerable plant products $[18,25]$. The release of numerous quality-degrading enzymes, such as polyphenol oxidases, cellulases, pectolytic enzymes, amylases, and peroxidases, causes serious sensory changes, such as discoloration, softening, the production of off-flavors and off-odors, etc. [26,27]. Another aspect of the dynamic behavior of such products is related to water loss, widely 
known as "transpiration." Fresh-cut plant tissues are reported to lose water to a higher extent than intact products, which is attributed to an increased surface-area-to-volume ratio resulting from cutting procedures during minimal processing. On the other hand, a chilled storage temperature $[28,29]$ and atmosphere composition may also cause several disorders since they affect both respiration rate and the nutritional quality of fresh-cut produce. Nevertheless, it is worth noticing that the fresh-cut product does not suffer from chilling injury, a disorder that is frequently observed in the intact counterpart [17]. Taking into consideration that all of these physiological pathways downgrade product sensory and nutritional quality, the challenge of the current research lies on testing potential hurdles in order to counteract this physiological decay, including low temperatures, edible coatings, antioxidants, acidulants, antimicrobial agents, ethylene inhibitors, MAP packaging, etc. In recent literature, there are several interesting studies on quality degradation of minimally processed fruits and vegetables due to physiological activity, namely for pomegranate [30], celery [31], broccoli [32], tomato [14], asparagus [33].

\subsection{Factors Related to Degradation of Sensory Characteristics}

\subsubsection{Water Loss}

Moisture loss as a result of transpiration during storage and transportation is a significant factor that affects the quality and marketability of sensitive products, such as fruits and vegetables. During postharvest handling, fresh fruits and vegetables tend to lose moisture through their skins, stomata, cuticle, and other structural components, especially when the surrounding atmosphere has low relative humidity. Transpiration phenomena are caused by a difference in water vapor pressure between the product surface and the environment $[18,26]$. It is worth mentioning that the evaporation occurring at the product surface is an endothermic process, which will decrease product temperature. Water loss depends on intrinsic factors, such as surface morphology, size, surface-to-weight and volume ratio, maturity stage, physical injuries, as well as extrinsic factors, such as temperature, relative humidity, and airflow around the product. As readily observed [26,34], some plant tissues are more prone to water loss, such as leafy vegetables, e.g., lettuce, which wilt and shrivel rapidly, whereas others, like apples and pears, are more resistant to water loss. Fresh-cut products are more susceptible to quality degradation than whole products due to the increased rates of transpiration caused by their increased surface-tovolume ratio. This water loss process has serious adverse effects on the quality attributes of such perishable commodities, including loss of turgidity, shriveling, wilting, and withering [35]. There are numerous studies measuring these indices in order to assess product degradation $[19,30,36-39]$.

\subsubsection{Texture Changes}

The texture attributes of plant tissues vary during postharvest handling, as they depend on many factors, such as the stage of maturity, water stress, storage temperature and relative humidity, rough handling, and the ripening process. Changes observed in several products include softening, turgor loss, and increased elasticity or toughness, leading to a significant product quality deterioration. These negative phenomena may be caused due to the transpiration process or the activity of several enzymes or mechanical injuries that occur during transport and storage. Enzymes, such as $\beta$-galactosidase, polygalacturonase, pectin methyl esterase, cellulose, phenylalanine ammonia-lyase, peroxidase, and cellulase, may lead to cell-wall modification and significant pectin degradation. Examples of such textural defects involve pectin degradation in strawberries [40] and tomatoes [39,40], toughness development in asparagus [33], loss of crispness in lettuce and spinach [41], hardness increase in carrot [19,42], firmness decrease in celery [38], mushiness in cantaloupe [43], changes in broccoli [32], etc. [44]. 


\subsubsection{Color Changes}

Color is considered one of the most decisive factors for a consumer's acceptance or rejection of commodities, such as fresh-cut fruits and vegetables, and is frequently used as an indicator of the overall quality level and maturity stage of the final product [17]. Color is significantly affected by factors, such as the particular cultivar, temperature and relative humidity conditions, and postharvest handling procedures. Color changes are induced by anabolic or catabolic reactions of pigment compounds, including chlorophylls (green), anthocyanins (red, blue, and purple), and carotenoids and flavonoids (yellow and orange) [45]. These changes may occur as a consequence of the ripening process, but they also can be induced by mechanical injuries on cell tissues during handling and fresh-cut processing. Another frequent cause of color degradation in fresh-cut fruits is associated with enzymatic activity (for example, of PPO (polyphenol oxidase) and POD (peroxidase)) that follows cell-wall damage, which enables the immediate contact of enzymes, substrates, and oxygen. The browning of apples, peaches, pears, avocados, etc., is considered a major defect of these commodities and depends on the presence of phenolic compounds (the necessary substrate), the activity of polyphenol oxidase (PPO), and the concentration of antioxidants within the fruit cells [46]. Bhatia et al. [30], Zhao et al. [36], Massolo et al. [31], Paulsen et al. [32], Kumar et al. [39], Sucheta et al. [40], and Lwin et al. [33] have studied the color changes of minimally processed fresh-cut produce as an index to describe product degradation.

\subsubsection{Flavor/Taste and Nutritional Changes (Changes of Composition)}

It is well known that the plant tissue's composition is constantly changing, not only during growth and ripening but also after harvest, leading to either positive or negative quality attributes [16]. Among those compositional modifications, the soluble solids content and acidity (and especially their ratio) is frequently used as a quality criterion for product selection for processing and time of harvest. Such changes are more pronounced for climacteric commodities since they continue to ripen even after harvest. Flavor characteristics of most fruits are greatly influenced by their sugar concentration (sweetness), organic acids (acidity), phenolic compounds (astringency), and specific volatiles (aroma) [45]. Volatile losses can be associated with the ripening process, unsuitable storage conditions, or enzymatic activity of the corresponding enzymes, such as peroxidases and lipoxygenases. As far as nutritional factors are concerned, fresh fruits and vegetables are considered good sources of vitamins, minerals, dietary fiber, and several types of compounds possessing an antioxidant activity (flavonoids, carotenoids, polyphenols, and other phytonutrients). A significant loss of such substances is measured during handling and processing and after harvest. These losses are mainly caused by physical damage of the cell wall, inappropriate conditions of temperature and relative humidity during storage, and chilling injury of sensitive commodities [45]. In Massolo et al. [31], Sucheta et al. [40], Zou et al. [22], Rodríguez-Arzuaga et al. [23], and Avalos-Llano et al. [24] sensory changes of selected fresh produce have been extensively studied.

\section{Hurdles Applied in the Preservation and Shelf-Life Extension of Fresh-Cut Fruits and Vegetables}

As frequently observed in relative surveys, consumers recently tend to prefer perishable foods with minimum but adequate processing, so the nutritional/sensory profile of the processed food will not be substantially altered. In this work, the focus is drawn on fresh-cut fruits and vegetables; minimally processed produce is reported as "the fruits and vegetables washed, physically processed (peeling, cutting, slicing or shredding), packaged and maintained with refrigeration" [6,47]. Being still-respiring matrices, the main difference from their raw counterparts is that the respiration process is increased by processes, such as cutting, slicing, low-temperature heat treatments, and preservatives [48]. Furthermore, they do not resemble dehydrated foods, especially due to their texture attributes and water activity $\left(\mathrm{a}_{\mathrm{w}}\right)$, which is higher than 0.95 . On the other hand, dehydrated plant tissues are 
handled as shelf-stable at ambient temperatures, and thus cold-chain management is not applied. As far as comparison with thermally processed foods is concerned, minimally processed fruits and vegetables cannot be considered as "commercially sterile."

Different types of hurdles can be used in fruit and vegetable processing, including thermal treatments, low-temperature storage, regulation of acidity, water activity decrease, the use of the appropriate preservatives, etc. [8-10]. In all cases, the selection and sequence of hurdles depend on the type of microorganisms, and the main purpose is to satisfy the safety standards without compromising the food quality and consumer health [49]. The careful and well-documented choice of hurdles, in addition to the intensity of each, and the sequence applied to obtain a specific safety and quality target, are expected to show significant potential for the future of minimally processed fruits and vegetables [50].

Regarding fresh-cut fruits and vegetables, as already discussed, the prevailing factors causing irreversible spoilage and organoleptic rejection are related to the potential microbial and enzymatic activity; thus, all potential preservation techniques, the so-called "hurdles," aim at an effective microbe and enzyme inhibition [48]. To obtain the desired shelf-life improvement, some traditional methods, such as heat preservation (preferring mild heat treatments), use of chemicals (e.g., acidulants, antioxidants, chlorine, antimicrobials, sanitizers, etc.), low-temperature preservation, application of proper irradiation, oxidation/reduction $(\mathrm{O} / \mathrm{R})$, decrease of water activity $\left(\mathrm{a}_{\mathrm{w}}\right)$, and appropriate packaging (e.g., Modified Atmosphere Packaging, MAP, edible coatings, etc.), can be effectively applied. The combined application of the aforementioned technologies, considering the synergistic effect of the different preservation hurdles or barriers, may be selected. These barriers take into consideration intact or destroyed enzyme systems in the living tissues, mainly polyphenol oxidase (PPO), peroxidase (PO), or pectinases, polygalacturonase (PG) and pectinesterase $(\mathrm{PE})$, and other respiratory-related enzymes.

Regarding fresh-cut fruits and vegetables, the washing step and the sanitation procedure play a significant role in the final food safety since these commodities are considered as "ready-to-eat" foods. The purpose is to remove pesticide residues, dirt and foreign objects, and microorganisms responsible for quality degradation and spoilage [51,52]. Besides the use of chemicals for disinfection, other physical technologies, such as heat treatments, UV-treatment, high pressure, pulsed electric field, pulsed light, oscillating magnetic fields, low-dose gamma irradiation, and ultrasound treatments, have been investigated to reduce or eliminate microorganisms, usually with more than one technique in an appropriate combination [52,53]. In this section, the main hurdles applied in fresh-cut fruits and vegetables are briefly described, and a Table (Table 1) including indicative studies is presented.

Table 1. Indicative studies on the application of hurdle technology on fresh-cut fruits and vegetables (Abbreviations: RPL: repetitive pulsed light; OD: osmotic dehydration; HHP: high hydrostatic pressure; SAEW: slightly acidic electrolyzed water; US: ultrasound; MH: mild heat treatment; AA: ascorbic acid; HR: 4-hexylresorcinol; CM: chamomile; MAP: modified atmosphere packaging; PP: polypropylene; GO: garlic oil; AIT: allyl isothiocyanate; TVC: total viable count; PME: pectin methylesterase; PG: polygalacturonase; TAA: total antiradical activity).

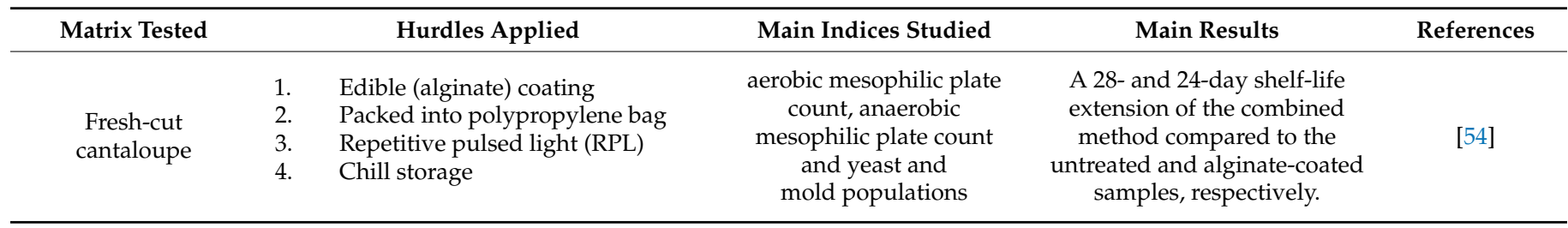


Table 1. Cont

\begin{tabular}{|c|c|c|c|c|c|}
\hline Matrix Tested & & Hurdles Applied & Main Indices Studied & Main Results & References \\
\hline Fresh-cut tomatoes & $\begin{array}{l}2 . \\
3 .\end{array}$ & $\begin{array}{l}\text { Osmotic dehydration (OD) in } \\
\text { concentrated solutions (glycerol } \\
(50 \% w / w) \text {, erythritol }(12.5 \% w / w) \text {, } \\
\text { sodium chloride }(3.5 \% w / w) \text {, } \\
\text { calcium chloride }(1.5 \% w / w) \text { and } \\
\text { Citrox }(0.2 \% w / w) \text { at a } \\
\left.\text { temperature of } 35^{\circ} \mathrm{C} \text { for } 90 \mathrm{~min}\right) \\
\text { High } \mathrm{Hydrostatic} \text { pressure }(\mathrm{HHP}) \\
\left(600 \mathrm{MPa}-25^{\circ} \mathrm{C} \text { for } 5 \mathrm{~min}\right) \\
\text { Chill storage }\end{array}$ & $\begin{array}{ll}\text { - } & \text { Total aerobic viable } \\
& \text { count (TVC) and } \\
& \text { yeasts and moulds } \\
\text { - } & \text { PME, PG } \\
\text { - } & \text { Lycopene } \\
\text { - } & \text { Color } \\
\text { - } & \text { Sensory evaluation }\end{array}$ & $\begin{array}{l}\text { A 74- and over } 240-\text { day } \\
\text { shelf-life extension of OD and } \\
\text { the combined method } \\
\text { (OD-HHP) compared to the } \\
\text { untreated samples, } \\
\text { respectively. }\end{array}$ & [55] \\
\hline Fresh-cut apple & $\begin{array}{l}1 . \\
2 . \\
3 . \\
4 .\end{array}$ & $\begin{array}{l}\text { Washing with chlorinated water } \\
\text { Dipping in ascorbic acid/calcium } \\
\text { chloride solution } \\
\text { Edible coating (pectin powder + } \\
\text { apple fiber) } \\
\text { Placed into transparent } \\
\text { polypropylene trays, sealed, with a } \\
64 \mu \mathrm{m} \text { thick polypropylene film } \\
\text { PL treatments }\end{array}$ & $\begin{array}{l}\text { - Antioxidant capacity } \\
\text { (DPPH method) } \\
\text { - Color/firmness } \\
\text { measurement } \\
\text { Mesophilic and } \\
\text { psychrophilic } \\
\text { aerobic } \\
\text { microorganisms, } \\
\text { yeasts, and molds } \\
\text { Sensory } \\
\text { acceptability }\end{array}$ & $\begin{array}{l}\text { 1. The combination of } \\
\text { Pectin coating and PL } \\
\text { resulted in an almost } 2 \\
\text { log CFU } \mathrm{g}^{-1} \text { reduction } \\
\text { of microbial counts, and } \\
\text { apple pieces exhibited } \\
\text { higher antioxidant } \\
\text { activity values. } \\
\text { Sensory attribute scores } \\
\text { did not fall below the } \\
\text { rejection limit during } \\
\text { 14 days. }\end{array}$ & {$[56]$} \\
\hline $\begin{array}{l}\text { Fresh-cut bell } \\
\text { peppers }\end{array}$ & $\begin{array}{l}1 . \\
2 . \\
3 .\end{array}$ & $\begin{array}{l}\text { Slightly acidic electrolyzed water } \\
\text { (SAEW) } \\
\text { Ultrasound (US) } \\
\text { Mild heat treatment (MH) at } 45,50 \text {, } \\
\text { and } 60^{\circ} \mathrm{C}\end{array}$ & $\begin{array}{l}\text { Listeria } \\
\text { monocytogenes and } \\
\text { Salmonella enterica } \\
\text { serovar Typhimurium } \\
\text { Texture and color } \\
\text { analysis }\end{array}$ & $\begin{array}{l}\text { The optimized condition of the } \\
\text { combined treatment was } \\
\text { SAEW }+ \text { US }+60^{\circ} \mathrm{C} \text { for } 1 \mathrm{~min} \text {, } \\
\text { with minimal changes in } \\
\text { quality indices }\end{array}$ & [57] \\
\hline Fresh-cut apple & & Ultrasound Ascorbic acid & $\begin{array}{l}\text { Enzyme inactivation } \\
\text { (monophenolase, } \\
\text { diphenolase, } \\
\text { and peroxidase) }\end{array}$ & $\begin{array}{l}\text { The combined application of } \\
\text { ultrasound and ascorbic acid } \\
\text { showed synergistic inhibitory } \\
\text { effects on enzymes related to } \\
\text { enzymatic browning. }\end{array}$ & {$[58]$} \\
\hline $\begin{array}{l}\text { Fresh-cut peach and } \\
\text { apricot }\end{array}$ & 2. & $\begin{array}{l}\text { Osmotic dehydration (OD) in } \\
\text { concentrated solutions (glycerol } \\
(50 \% w / w) \text {, erythritol }(12.5 \% w / w) \text {, } \\
\text { sodium chloride }(3.5 \% w / w) \text {, } \\
\text { calcium chloride }(1.5 \% w / w) \text { and } \\
\text { Citrox }(0.2 \% w / w) \text { at a } \\
\left.\text { temperature of } 45^{\circ} \mathrm{C} \text { for } 45 \mathrm{~min}\right) \\
\text { High } \mathrm{Hydrostatic} \text { pressure }(\mathrm{HHP}) \\
\left(600 \mathrm{MPa}-25^{\circ} \mathrm{C} \text { for } 5 \text { min) Chill }\right. \\
\text { storage }\end{array}$ & $\begin{array}{ll}\text { - } & \text { Total aerobic viable } \\
\text { count (TVC) and } \\
\text { yeasts and moulds } \\
\text { - } \quad \text { Color } \\
\text { - } \quad \text { Sensory evaluation } \\
\text { - } \quad \text { Texture }\end{array}$ & $\begin{array}{l}\text { Shelf-life estimated at } 309 \text { and } \\
320 \text { days at } 4{ }^{\circ} \mathrm{C} \text {, for OD/HP } \\
\text { peach and apricot, respectively, } \\
\text { compared to approximately } \\
68-86 \text { days, for OD samples, } \\
\text { when non-treated samples are } \\
\text { expected with a shelf life of } \\
5-7 \text { days at cold storage. }\end{array}$ & [59] \\
\hline Fresh-cut apples & $\begin{array}{l}1 . \\
2 .\end{array}$ & $\begin{array}{l}\text { carboxymethyl cellulose } \\
\text { (CMC)and aloe vera coatings } \\
\text { antibrowning agents (ascorbic acid } \\
(\mathrm{AA}), \mathrm{CaCl}_{2} \text {, cysteine, } \\
\text { 4-hexylresorcinol (HR)) } \\
\text { Samples packaged in } \\
\text { polypropylene containers, } \\
\text { shrink-wrapped, and stored at } \\
5 \pm 2{ }^{\circ} \mathrm{C}\end{array}$ & $\begin{array}{l}\text { Ascorbic acid, total } \\
\text { phenols, and } \\
\text { antioxidant activity } \\
\text { Polyphenol oxidase } \\
\text { and peroxidase } \\
\text { activity } \\
\text { - } \quad \text { Sensory evaluation } \\
\text { - } \quad \text { Microbial } \\
\text { enumeration } \\
\text { Browning and } \\
\text { whiteness index } \\
\text { Weight loss and } \\
\text { fruit firmness }\end{array}$ & $\begin{array}{c}\text { Combined application of CMC } \\
(1 \%) \text { with } \mathrm{HR}(0.01 \%)+\mathrm{AA} \\
(0.5 \%)+\mathrm{CaCl} 2(0.2 \%)-\text { the } \\
\text { most effective treatment for } \\
\text { quality preservation and } \\
\text { reduction of surface browning } \\
\text { in fresh-cut wedges during } \\
\text { storage for } 7 \text { days at } 5 \pm 2{ }^{\circ} \mathrm{C} \text {. }\end{array}$ & {$[60]$} \\
\hline
\end{tabular}


Table 1. Cont.

\begin{tabular}{|c|c|c|c|c|c|}
\hline Matrix Tested & & Hurdles Applied & Main Indices Studied & Main Results & References \\
\hline Fresh-cut lotus roots & $\begin{array}{l}1 . \\
2 . \\
3 .\end{array}$ & $\begin{array}{l}\text { antibrowning agents (ascorbic acid } \\
(\mathrm{AA}) \text {, chamomile }(\mathrm{CM})) \\
\text { heat treatment }\left(55^{\circ} \mathrm{C} \text { for } 45 \mathrm{~s}\right) \\
\text { MAP packaging }(\text { air, vacuum, } \\
\left.100 \% \mathrm{CO}_{2}, 50 \% \mathrm{CO}_{2} / 50 \% \mathrm{~N}_{2}\right)\end{array}$ & $\begin{array}{ll}\text { - } & \text { color } \\
\text { - } & \text { weight loss } \\
\text { - } & \text { texture } \\
\text { - } & \text { pH } \\
\text { - } & \text { polyphenoloxidase } \\
& \text { activity } \\
\text { - } & \text { total phenolic } \\
& \text { content }\end{array}$ & $\begin{array}{l}\text { Dipping in an } \mathrm{AA}+\mathrm{CM} \\
\text { antibrowning treatment and } \\
100 \% \mathrm{CO}_{2} \mathrm{MAP} \text { with a heat } \\
\text { treatment extended the } \\
\text { shelf-life to } 21 \text { days at } 5^{\circ} \mathrm{C} \text {. }\end{array}$ & [61] \\
\hline Fresh-cut apples & 2. & $\begin{array}{l}\text { antibrowning agents (ascorbic } 1 \\
\text { citric acid; ascorbic acid } 1 \mathrm{NaCl} \text {; } \\
\mathrm{NaCl} \text {, citric acid, and } \mathrm{Ca} \text {-ascorbate) } \\
\text { Ultrasound ( } 1 \text { and } 3 \mathrm{~min} \text { ) }\end{array}$ & $\begin{array}{ll}- & \text { Determination of } \\
& \text { soluble solids } \\
& \text { content and } \mathrm{pH} \\
\text { - } \quad \text { Color } \\
\text { - } & \text { Sensory evaluation }\end{array}$ & $\begin{array}{l}\text { 1. The most effective } \\
\text { antibrowning solution } \\
\text { was Ca-ascorbate. } \\
\text { 2. } \\
\text { USger application of } \\
\text { the prevention of } \\
\text { browning in } \\
\text { fresh-cut apples. }\end{array}$ & [62] \\
\hline $\begin{array}{l}\text { Fresh-cut } \\
\text { strawberry }\end{array}$ & $\begin{array}{l}2 . \\
3 .\end{array}$ & $\begin{array}{l}\text { Osmotic dehydration (OD) in } \\
\text { concentrated solutions (glycerol } \\
(50 \% w / w) \text {, erythritol }(12.5 \% w / w) \text {, } \\
\text { ascorbic acid }(2.0 \% w / w) \text {, calcium } \\
\text { chloride }(1.5 \% w / w) \text {, citric acid } \\
1.0 \% w / w), \mathrm{Citrox}(0.1 \% w / w) \text { and } \\
\mathrm{L}-\mathrm{cysteine} \mathrm{HCl}(0.20 \% w / w) \text { at } 15 \text {, } \\
25,35 \text {, and } 45^{\circ} \mathrm{C} \text { for times up to } \\
300 \text { min } \\
\text { High Hydrostatic pressure (HHP) } \\
\left(600 \text { MPa }-25^{\circ} \mathrm{C} \text { for } 5 \text { min) }\right. \\
\text { Chill storage }\end{array}$ & $\begin{array}{ll}\text { - } & \text { Total aerobic viable } \\
& \text { count (TVC) and } \\
& \text { yeasts and moulds } \\
\text { - } & \text { Color } \\
\text { - } & \text { Sensory evaluation } \\
\text { - } & \text { Total antiradical } \\
& \text { activity (TAA) } \\
\text { - } & \text { Identification of } \\
& \text { anthocyanins } \\
\text { - } & \text { Texture }\end{array}$ & $\begin{array}{l}\text { Shelf life was significantly } \\
\text { extended for both OHP and } \\
\text { OD (up to } 10 \text { and } 4 \text { months at } \\
5^{\circ} \mathrm{C} \text {, respectively) compared } \\
\text { to untreated samples ( }(7 \text { days } \\
\text { at } 5^{\circ} \mathrm{C} \text { ). The addition of } \\
\text { L-cysteine added in the OD } \\
\text { solution exhibited an } \\
\text { exceptional red color intensity } \\
\text { and stability. }\end{array}$ & [63] \\
\hline Fresh-cut rocket & $\begin{array}{l}1 . \\
2 . \\
3 .\end{array}$ & $\begin{array}{l}\text { UV-C radiation }(5,10 \text {, and } 20 \\
\left.\mathrm{kJ} / \mathrm{m}^{2}\right) \\
\text { gaseous ozone }(1,2 \text { and } 5 \mathrm{ppm} \text { for } \\
10 \mathrm{~min}) \\
\text { placed in polypropylene }(\mathrm{PP}) \text { trays } \\
\text { were sealed at the top with a } \\
\text { bioriented PP film of } 35 \mu \mathrm{m} \\
\text { (passive MAP) } \\
\text { cold storage }\end{array}$ & $\begin{array}{ll}\text { - } & \text { Chlorophyll and } \\
& \text { Carotenoid Content } \\
\text { - } & \text { Color } \\
\text { - } & \text { Sensory evaluation } \\
\text { Enumeration of } \\
\text { mesophilic, } \\
\text { psychrotrophic and } \\
\text { enterobacteria, } \\
\text { molds, and yeasts }\end{array}$ & $\begin{array}{l}\text { The } 20 \mathrm{~kJ} \mathrm{UV-C} / \mathrm{m}^{2} \text { treatment } \\
\text { reduced the microbial load of } \\
\text { the fresh-cut rocket during } 8 \\
\text { days of storage at } 5^{\circ} \mathrm{C} \text {. }\end{array}$ & [64] \\
\hline Freshcut pear cubes & $\begin{array}{l}2 . \\
3 .\end{array}$ & $\begin{array}{l}\text { Blanching at } 95^{\circ} \mathrm{C} \text { for } 3 \mathrm{~min} \text { in a } 17 \\
{ }^{\circ} \text { Brix aqueous solution containing } \\
\text { High Fructose Corn Syrup and } \\
\text { citric acid } \\
\text { MAP }\left(\mathrm{N}_{2} / \mathrm{CO}_{2}(80: 20 v / v)\right) \\
\text { cold storage }\end{array}$ & $\begin{array}{ll}\text { - } & \text { Color } \\
\text { - } & \text { Drip loss } \\
\text { - } & \text { Firmness } \\
\text { - } & \text { Total aerobic } \\
& \text { population, yeasts } \\
\text { and molds, } \\
\text { Pseudomonadaceae, } \\
\text { and total coliforms }\end{array}$ & $\begin{array}{c}\text { The combination of mild heat } \\
\text { treatment ( } 3 \text { min at } \\
\left.95^{\circ} \mathrm{C}\right) / \text { MAP under aseptic } \\
\text { conditions improved } \\
\text { the stability. }\end{array}$ & [65] \\
\hline $\begin{array}{l}\text { Fresh-cut leafy salad } \\
\text { (lollo rosso lettuce, } \\
\text { lollo verde lettuce, } \\
\text { and rocket) }\end{array}$ & $\begin{array}{l}1 . \\
2 .\end{array}$ & $\begin{array}{l}\text { Low temperature } \\
\operatorname{MAP}\left(3 \% \mathrm{O}_{2}, 10 \% \mathrm{CO}_{2}, 87 \% \mathrm{~N}_{2}\right)\end{array}$ & $\begin{array}{l}\text { Total viable count, } \\
\text { Pseudomonas spp., lactic } \\
\text { acid bacteria, vitamin C, } \\
\text { color, and texture }\end{array}$ & $\begin{array}{l}\text { Development and validation } \\
\text { of adequate predictive } \\
\text { shelf-life models. }\end{array}$ & [66] \\
\hline Dandelion leaves & $\begin{array}{l}1 . \\
2 .\end{array}$ & $\begin{array}{l}\text { Low temperature } \\
\text { MAP }\left(22 \% \mathrm{CO}_{2}-78 \% \mathrm{~N}_{2}\right)\end{array}$ & $\begin{array}{l}\text { Total viable count, } \\
\text { Pseudomonas spp., } \\
\text { lactobacilli, yeasts, and } \\
\text { molds, Enterobacteriaceae } \\
\text { spp., texture, enzymatic } \\
\text { activity, vitamin C } \\
\text { concentration and sensory } \\
\text { evaluation }\end{array}$ & $\begin{array}{l}\text { MAP resulted in a 1-day } \\
\text { extension of shelf life } \\
\text { compared to conventional } \\
\text { aerobic storage in perforated } \\
\text { films. Development and } \\
\text { validation of adequate } \\
\text { predictive shelf-life models. }\end{array}$ & [67] \\
\hline $\begin{array}{l}\text { Plum and } \\
\text { strawberry }\end{array}$ & $\begin{array}{l}1 . \\
2 .\end{array}$ & $\begin{array}{l}\text { Low temperature } \\
\text { Modified atmosphere and } \\
\text { humidity packaging }\end{array}$ & $\begin{array}{l}\text { Moisture loss, gas and } \\
\text { water vapor transfer }\end{array}$ & $\begin{array}{l}\text { Development and validation } \\
\text { of adequate simulation } \\
\text { program for the preservation } \\
\text { of packed fruit. }\end{array}$ & [13] \\
\hline
\end{tabular}


Table 1. Cont.

\begin{tabular}{|c|c|c|c|c|}
\hline Matrix Tested & Hurdles Applied & Main Indices Studied & Main Results & References \\
\hline $\begin{array}{l}\text { Peach and cherry } \\
\text { tomatoes }\end{array}$ & $\begin{array}{l}\text { Low temperature } \\
\text { Equilibrium modified atmosphere } \\
\text { packaging }\left(1-3 \% \mathrm{CO}_{2}, 85 \% \mathrm{RH}\right)\end{array}$ & $\begin{array}{l}\text { In package } \mathrm{CO}_{2}, \mathrm{O}_{2}, \\
\text { and } \mathrm{C}_{2} \mathrm{H}_{4}\end{array}$ & $\begin{array}{l}\text { Biodegradable } \\
\text { laser-microperforated PLA } \\
\text { films were designed for fruit } \\
\text { packaging and preservation. }\end{array}$ & [68] \\
\hline Fresh-cut tomatoes & $\begin{array}{l}\text { Low temperature } \\
\text { Active pads with encapsulated } \\
\text { garlic oil (GO) }\end{array}$ & $\begin{array}{l}\text { GO volatile release, total } \\
\text { viable count, yeasts and } \\
\text { molds, coliforms and } \\
\text { E. coli, sensory evaluation }\end{array}$ & $\begin{array}{l}\text { Tomato was affected by the } \\
\text { highest concentration of GO } \\
\text { capsules, showing lower } \\
\text { microbial growth and higher } \\
\text { sensory quality. }\end{array}$ & [69] \\
\hline Papaya & $\begin{array}{l}\text { Antimicrobial sachet containing } \\
\text { oregano, cinnamon, and } \\
\text { lemongrass EO }\end{array}$ & $\begin{array}{l}\text { Antifungal activity, } \\
\text { weight loss, peel } \\
\text { colour and firmness, } \\
\text { total soluble solids, } \\
\text { titratable acidity }\end{array}$ & $\begin{array}{l}\text { Sachets containing cinnamon, } \\
\text { oregano, and lemongrass } \\
\text { resulted in a significant } \\
\text { reduction in the growth of } \\
\text { mesophilic aerobic bacteria, } \\
\text { yeasts, and molds. }\end{array}$ & [70] \\
\hline Fresh spinach & $\begin{array}{l}\text { Low temperature } \\
\text { Antimicrobial sachet containing } \\
\text { allyl isothiocyanate (AIT) vapor }\end{array}$ & $\begin{array}{c}\text { AIT release, antimicrobial } \\
\text { effect against } E \text {. coli } \\
\text { O1§75:H7, yeasts, and } \\
\text { moulds }\end{array}$ & $\begin{array}{c}\text { The load of E. coli O157:H7 on } \\
\text { spinach leaves decreased by } \\
1.6-2.6 \log \mathrm{CFU} / \text { leaf at } 4{ }^{\circ} \mathrm{C} \\
\text { and } 2.1-5.7 \log \mathrm{CFU} / \text { leaf at } \\
25^{\circ} \mathrm{C} \text { within } 5 \text { days. } \\
\text { Mango showed quality }\end{array}$ & [71] \\
\hline Mangoes & $\begin{array}{l}\text { Low temperature } \\
\text { Antimicrobial film coated with } \\
\text { chlorine dioxide microcapsules }\end{array}$ & $\begin{array}{l}\text { Weight loss, firmness, } \\
\text { colour, soluble solids, } \\
\text { vitamin C, titratable acid, } \\
\text { and nutritional value }\end{array}$ & $\begin{array}{l}\text { Mango showed quality } \\
\text { degradation after } 21 \text { days of } \\
\text { storage. The chlorine dioxide } \\
\text { microcapsule antibacterial film } \\
\text { preserved the high quality for } \\
\text { longer storage periods. }\end{array}$ & [72] \\
\hline Tomatoes & $\begin{array}{l}\text { Low temperature } \\
\text { Chitosan coating }\end{array}$ & Respiration rate, ethylene & $\begin{array}{l}\text { Coating increased the internal } \\
\mathrm{CO}_{2} \text { concentration and } \\
\text { decreased the internal } \mathrm{O}_{2} \\
\text { levels in tomato samples. }\end{array}$ & [73] \\
\hline Cherry tomatoes & $\begin{array}{ll}\text { 1. } & \text { Low temperature } \\
\text { 2. } & \text { Edible coatings }\end{array}$ & $\begin{array}{l}\text { Color, weight loss, } \\
\text { firmness, soluble solids, } \\
\text { pH, and molds and yeasts }\end{array}$ & $\begin{array}{l}\text { The edible coating with } \\
\text { protein hydrolysate inhibited } \\
\text { the proliferation of molds } \\
\text { and yeasts. }\end{array}$ & [74] \\
\hline Tomatoes & $\begin{array}{c}\text { Edible coating with Flourensia cernua } \\
\text { extract }\end{array}$ & $\begin{array}{l}\text { Sensory evaluation, } \\
\text { weight loss, firmness, } \mathrm{pH}, \\
\text { colour }\end{array}$ & $\begin{array}{l}\text { The edible coating } \\
\text { incorporated with F. cernua } \\
\text { extract was the most effective } \\
\text { in delaying pathogenic fungi } \\
\text { growth and preserving the } \\
\text { visual appearance of the final } \\
\text { product at the end of the } \\
\text { storage period. }\end{array}$ & [75] \\
\hline Peach & $\begin{array}{l}\text { Low temperature } \\
\text { Edible coating containing } \\
\text { 1-Methylcyclopropene and } \\
\text { Aloe arborescens }\end{array}$ & $\begin{array}{c}\text { Carotenoids content, } \\
\text { phenolic content, reducing } \\
\text { activity, titratable acidity, } \\
\text { total soluble content, } \\
\text { weight loss, and vitamin } \\
\text { C content }\end{array}$ & $\begin{array}{l}\text { The single and combined } \\
\text { application of aloe-based } \\
\text { coating slowed down the } \\
\text { maturation processes of the } \\
\text { fruit, delayed the weight loss, } \\
\text { and preserved the sensory } \\
\text { properties of the } \\
\text { final products. }\end{array}$ & [76] \\
\hline
\end{tabular}

\subsection{Conventional Hurdles}

\subsubsection{Short Time Heat Treatments}

This is one of the oldest and most popular forms of preservation, which aims at reducing microorganisms and inhibiting enzyme activity in plant tissues (the well-known blanching step). The major problem in such perishable products is that heat is associated with significant degradation of flavor, texture, color, and nutritional quality. The main treatments applied in fresh-cut fruits and vegetables include short-time hot water treatments [77-81] that aim to control the fresh produce surface microflora. Other heat treatments include hot water rinsing and brushing (HWRB) [82], mild Heat Shock [50,83], hot water blanching [42,84], etc. As discussed in Sivakumar and Fallik [82], short-time heat treatments are becoming more attractive in the fresh-cut produce industry as an effective 
means of preventing the negative effects of enzymatic browning and an alternative to chemical preservation.

\subsubsection{Low Temperatures}

Chilled storage after treatment is a necessary step in fresh-cut fruits and vegetables, aiming at slowing down microbial growth and inhibiting extensive enzyme activity. Precooling is a common treatment step frequently applied by fresh horticultural produce industries due to its low cost, simplicity, and convenience $[33,85]$.

\subsubsection{Chemical Preservation (with or without $\mathrm{pH}$ Control)}

This category of hurdles is very important for fresh-cut fruits and minimally processed plant tissues because it includes agents used for washing and sanitizing purposes [50]. The food industry relies on wash-water sanitizers to decrease initial bacterial populations immediately after cutting and as a tool to preserve their quality and extend their shelf life [51]. Some of the common chemicals include chlorine-based compounds (hypochlorite, chlorine dioxide, acidified sodium chlorite, electrolyzed oxidizing water, etc.), organic acid formulations, hydrogen peroxide $\left(\mathrm{H}_{2} \mathrm{O}_{2}\right)$, ozonated water and gaseous ozone $\left(\mathrm{O}_{3}\right)$, alkaline products, and iodine detergent products. In recent literature, there are numerous investigations reporting the effective use of chemical compounds for sanitizing fresh-cut produce [86-90].

Besides washing and sanitizing agents, other chemical compounds have been extensively applied to inhibit microbial spoilage and preserve the quality of low-acid vegetablebased products, acidified low-acid products, and high-acid fruit products. Such substances include antimicrobials, such as organic acids, medium-chain fatty acids, fatty acid esters of polyhydric acids, sugar and salt, L-ascorbic acid, and EDTA [91]; those preservatives that act as antioxidants are widely used to prevent enzymatic browning, inhibit pigment discoloration, and protect against the loss of sensory and nutritional attributes. In Gurtler et al. [92], a review is presented on cases where antimicrobial compounds and mild thermal processing have been used in combination to enhance the inactivation of foodborne pathogen populations in perishable foods, including cut lettuce, cut or shredded cabbage, shredded carrot, and baby spinach leaves.

\subsubsection{Water Activity Decrease}

Water activity reduction can be a very effective way to limit microbial and enzyme activity because the majority of fresh-cut fruits and vegetables have an $a_{w} \geq 0.98$. This method involves either the removal of a certain amount of moisture from the foods (a type of dehydration) or the simultaneous impregnation in a medium or high osmotic pressure (osmotic treatment). It is obvious that the reduction of water activity cannot be used as the sole "hurdle" since that would lead to extensive dehydration of the matrix with unpleasant effects on the nutritional and sensory attributes of the raw tissue. As will be shown through specific examples, the use of $\mathrm{a}_{\mathrm{w}}$ reduction in combination with another preservation method can be an effective way to retain raw material superior quality, extending its shelf life at the same time. This hurdle is implemented in Dermesonlouoglou et al. [55] and Medina et al. [93].

\subsubsection{Biological Methods (Biopreservation)}

This process is mainly based on the use of natural or controlled microflora, such as lactic acid bacteria and/or metabolites, to improve the shelf life and the safety of food products [94]. This species is known to produce numerous antimicrobial metabolic compounds, such as bacteriocins, diacetyl, hydrogen peroxide, and organic acids, which may show a detrimental effect on pathogenic microorganisms [95,96]. 


\subsection{Emerging Techniques in the Hurdle Integrated Technology}

Recent developments in hurdle technology involve the introduction of innovative techniques as part of the hurdle sequence [97,98], for example HHP [55,99,100], PEF [101,102], UV-C (short-wave ultraviolet) [100,103,104], ozone [105], pulsed light [106], High Power Ultrasound [100], natural antioxidants extracted from food waste, etc. In Alzamora et al. [97], an overview of the main emerging "nonthermal" factors is presented, together with their mode of action, potential advantages and disadvantages, and the combined processes (complimentary hurdles), which have been used for fruit preservation. In another interesting recent publication, the most important innovative developments applied to fresh-cut fruits are presented, including physical, chemical, and biopreservation methods. High Hydrostatic Pressure (HHP) is a technique that is based on the instantaneous and uniform application of pressure around $100-800 \mathrm{MPa}$, below $0-100{ }^{\circ} \mathrm{C}$, from seconds to about $20 \mathrm{~min}$, aiming at membrane disruption, protein denaturation, leakage of vegetative cell content, and dissociation of ribosomes. Short-wave ultraviolet light (UV-C) is radiation from the $200-280 \mathrm{~nm}$ region of the electromagnetic spectrum. This technique is well known to cause extensive damage to DNA, membrane integrity, and enzyme activity. Regarding fresh-cut fruits or minimally processed vegetables, UV-C disinfection is a common procedure in the postharvest treatment for the surface inactivation of microorganisms [53], followed by other hurdles, such as MAP or cold storage, for a further shelf-life extension. Pulsed Electric Fields (PEF) involves the application of short electrical pulses of high voltage $(5-50 \mathrm{kV} / \mathrm{cm}$, pulse duration few $\mu \mathrm{s})$ for microbial inactivation while retaining the plant food superior quality. The underlying mechanism is the disruption of the cell membrane and the loss of membrane permeability. The high-power ultrasound (US) technique is based on energy generation by sound waves $\left(5 \mathrm{~W} / \mathrm{cm}^{2} ; 20-100 \mathrm{kHz}\right)$, and it is well known to cause extensive cellular damage and cell lysis attributed to cavitation. Another emerging hurdle is pulsed light (PL), which is based on high-intensity light pulses of short durations within a wide wavelength range, from ultraviolet to the near-infrared region (200-1100 nm). Besides the significant microbial reduction obtained in a very short treatment time due to DNA and cellular components damage, its low environmental impact and high flexibility are the main benefits of the PL technique [106]. Cold plasma is another nonthermal processing technology that aims at reducing microbial populations on produce surfaces as an alternative to chemical disinfecting agents $[100,107,108]$. Recently, scientific research has investigated the potential of using dense phase carbon dioxide $\left(\mathrm{DP}-\mathrm{CO}_{2}\right)$ as an alternative nonthermal treatment to inactivate microorganisms and enzymes in minimally processed fruits and vegetables [108-111]. Another interesting "hurdle" involves the use of natural compounds with antioxidant capacity as an effective substitute for synthetic additives. Additionally, the benefits of such an approach are maximized when those bioactive compounds are extracted from food industry byproducts, as a part of sustainable exploitation of food waste. In Venturi et al. [112], high-added-value antioxidant compounds were extracted from organic potato byproducts and were effectively applied in the pretreatment of cubes of fresh-cut apple, replacing other potentially hazardous chemicals successfully. Similar positive findings regarding the benefits of exploiting food byproducts for extending the short shelf life of several cut horticultural products are presented in $[113,114]$.

The preservation using irradiation includes infrared heating, microwave, UV-light, ionizing irradiation, etc. Electron Beam Irradiation (EBM), a method that does not require radioactive isotopes to generate ionizing radiation, has been shown to cause significant reduction of pathogenic microorganisms and has the potential to increase the shelf life and maintain the freshness of fresh-cut fruits [95,115-117].

An illustrative presentation of the hurdle concept application is presented in Figure 2, for some indicative cases of Table 1. In Figure 2A, a fresh-cut product (peaches and apricots) receives a short heat treatment (blanching) in order to reduce the level of remaining enzymes and decrease the initial microbial load present in the raw material. The second hurdle involves the simultaneous application of an $a_{w}$-lowering process, namely the osmotic dehydration of cut pieces, immersed in a solution containing a preservative 
agent (a natural antimicrobial product-signaled as $\mathrm{P}$ ), which directly affects the microbial systems. The High Hydrostatic Pressure (HHP) step aims at both enzyme inhibition and an additional microbial inactivation (cold pasteurization). This product would be packaged and retained at low temperatures throughout its shelf life during storage, distribution, and marketing (data obtained from Dermesonlouoglou et al. [59]). In Figure 2B, fresh-cut apples are first washed with chlorinated water (slight microbial reduction) and then dipped into an ascorbic acid/calcium chloride solution, lowering the $\mathrm{pH}$ and causing an antibrowning effect (through enzyme inactivation). The next hurdle involves an edible-coating treatment, which reduces respiration, water loss, and oxidation reaction rates, which slightly affects both enzyme and microbial inactivation. Finally, a pulsed-light treatment is conducted, aiming at a further microbial reduction. This product would be packaged and retained at low temperatures throughout its shelf life during storage, distribution, and marketing (data obtained from Moreira et al. [56]).
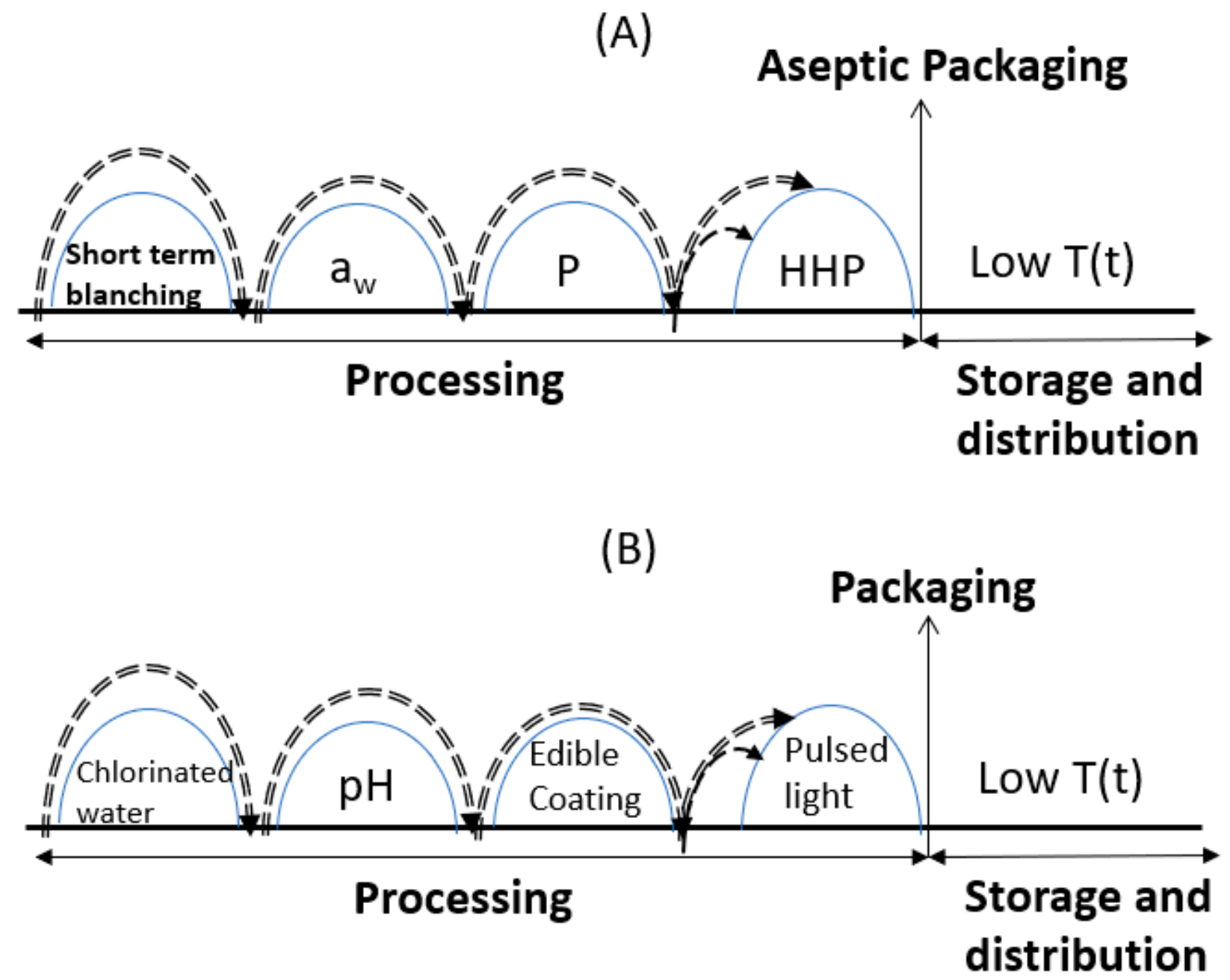

Figure 2. Indicative examples of the hurdle concept on the preservation of fruits, based on (A) Dermesonlouoglou et al. [59] and (B) Moreira et al. [56].

\section{Protection of Fruits and Vegetables by Appropriate Packaging Methods}

The major concern in purchasing ready-to-eat fresh-cut fruits and vegetable products refers to their short shelf life as a result of the rapid quality deterioration at the postharvest stages, which results in undesirable appearance and decreased palatability. For example, pre-packed fresh-cut leafy salads are significantly perishable, and their shelf life under refrigeration $\left(\leq 5^{\circ} \mathrm{C}\right)$ ranges between 7 and 10 days. The shelf life of fruits and vegetables 
can be calculated based on bacterial and chemical modifications. The complex indigenous spoilage microflora comprises Pseudomonas spp., lactic acid bacteria, Enterobacteriaceae spp., yeasts, and molds. Additional factors affecting the quality may be browning and enzymatic softening, which may be partially be attributed to enzymes from microorganisms [66,118, 119].

The use of appropriate packaging is necessary for the minimization of physical damage of fruits and vegetables and to obtain an optimal shelf life. In some cases, selected types of packaging (for example, healthy, fun, plain, etc.) of fruits and vegetable products may be selected in order to influence specific target groups' (e.g., children) health and taste evaluation. According to Dial et al. [120], children have been influenced by some aspects of packaging, rating healthy and fun packaging similarly. In general, the most commonly used method of packaging for fresh produce is the application of a fiberboard carton; however, in most cases, an additional internal packaging layer is appropriate in order to limit damage from abrasion. For this purpose, tissue paper wraps, trays, cups, or pads may be used. In the case of very delicate fruits, small packs with relatively few layers of fruits are applied for the reduction of compression and additional protection from damage. Fruits may also be wrapped individually using tissue or waxed paper. This technique may reduce the contamination with disease organisms within a package [12].

Smart packaging, considering active packaging methods and quality management tools, such as gas and moisture control, antimicrobial and/or antioxidant packaging systems, smart labels, and edible films or coatings, may be considered as novel packaging methods, which have been reported to result in improved quality and prolonged shelf life of sensitive food products.

\subsection{Gas and Controlled/Modified Atmosphere, Edible Coatings and Other Forms of Packaging} (This Will Be Described in Detail in the Following Section)

Modified atmosphere packaging (MAP) is a method of food preservation which has been originally designed for the packaging of fresh produce. Alternative polymeric films have been applied to pack fresh products for over forty years. Several of benefits have been reported in literature, including limitation of water loss, protection from skin abrasion and inhibition of microbial contamination during production and storage. A barrier to the spread of decay from one unit to another has been also provided [46]. Packaging films may also prevent the flow of respiratory gases, based on the relative permeability of the applied packaging films. This may result in the development of lowered $\mathrm{O}_{2}$ and higher $\mathrm{CO}_{2}$ concentrations in the package headspace and, as with control atmosphere storage (CAS), this may result in reduction of the respiration rate of the product and thus potentially prolong shelf life [12].

MAP may be considered as an active or passive dynamic packaging system, aiming at modifying the heaqdspace gas concentration within the food package. The passive approach relies on the application of the natural initial gaseous composition and the interaction between the product respiration rate gas permeability through the packaging. In the active approach of MAP, gases of required composition are flushed into the food packaging so as to achieve a rapid equilibrium atmosphere [13]. Improper control of respiration may result to undesirable phenomena from low oxygen levels to anaerobic respiration, accelerated physiological decay and limited shelf life [121]. Appropriate design of modified atmosphere and humidity packaging of fresh fruits and vegetable products has been the main objective of several research studies. Tsironi et al. [66] developed and validated the applicability of an Arrhenius type model for shelf-life prediction of ready-to-eat fresh cut salads (lollo rosso lettuce, lollo verde lettuce and rocket), in realistic distribution temperature conditions in the food supply chain. The quality level and shelf life calculated after 2-3 days of simulated domestic storage (corresponding to the time of consumption) ranged $1-8$ days at $4{ }^{\circ} \mathrm{C}$ and was predicted within acceptable statistical variations by the validated kinetic models.

Dermesonlouoglou et al. [67] developed shelf-life models for dandelion, that allowed for clalculations of the quality level and shelf life under alternative packaging types and 
storage temperatures. Microbial growth and modifications of different quality indices of dandelion packed in air-perforated films and under modified atmospheres were evaluated under different storage conditions. Jalali et al. [13] proposed a mathematical model for the prediction of the dependent variables of packaging design, as for example gas composition in the headspace, humidity and water vapour condensation dynamics under different environmental conditions, resembling the real supply chain for fresh fruits and vegetable products (such as plum and strawberry), based on specific properties of fresh food products and packaging materials. Recently, advanced techniques, as for example equilibrium MAP for dynamic modification of the headspace atmosphere have been applied for the extension of shelf life of high value fresh produce [122]. Successful applications of equilibrium modified atmosphere packaging include a wide variety of fresh plant-based products, such as broccoli, cauliflower and carrots [123], peach and cherry tomatoes [68]. A main disadvantage of this method is the extensive use of plastic materials, which may result in large amounts of plastic waste. At the same time, this method of packaging requires low temperature storage, i.e., $0-5{ }^{\circ} \mathrm{C}$, in order to maximize the shelf life of the packaged products. As the storage temperature increases, $\mathrm{O}_{2}$ requirements from tissues increase as well, while tolerance to $\mathrm{CO}_{2}$ decreases [68].

\subsection{Active Packaging of Fruits and Vegetables (Including Antimicrobial Packaging)}

In addition to the appropriate function for protection and assurance of the safety and integrity of the foods, recently, the application of packaging targets complementary functionalities. Smart packaging can contribute to shelf-life extension and may provide crucial information about the safety and quality level of food; and thus, it can enable the efficient management of the cold chain, minimization of food waste, and enhancement of consumer protection and public health. The "smartness" of packaging is based on the possibility to communicate critical information regarding food quality, such as package integrity and the time-temperature history of the packaged food product. Smart packaging may also provide direct information to the users about the quality level of the particular food, such as the freshness indicators that may provide information regarding the freshness and quality of the packaged food [124-126].

According to the EU Guidance to the Commission Regulation (EC) No 450/2009, the packaging is considered as active in case that it provides functions beyond the conventional protection and inert barrier to the external environment [127]. The main difference between intelligent and active packaging is that active packaging involves appropriate detection and response to modifications of the internal or external environment in order to adjust the properties of the package. Intelligent packaging turns on and off based on modifications of the external or internal environmental factors and communicates information to the consumer regarding the quality level of the packaged food [128,129]. Intelligent materials are defined on the basis of EC/450/2009 as tools that track the status of packaged food or its surrounding environment.

Active packaging includes different aspects, such as physiological processes (for example, fresh fruit and vegetable respiration), chemical modifications (for example, lipid oxidation), physical changes (for example, loss of moisture), and microbial activity (e.g., microbial), which may influence the shelf life of packaged fruits and vegetables. Through the implementation of suitable active packaging systems, these conditions can be handled in several different ways and in turn, the quality deterioration may be significantly delayed depending on the requirements of the packaged product. The specific functionality of active packaging depends on the active compounds that are incorporated into the packaging system. For instance, an antimicrobial active packaging system is based on the incorporation of antimicrobial compounds into the packaging material with the aim to delay or prevent microbial growth or contamination at all stages from transportation to the final consumption [6].

The presence of oxygen in fresh food packages may have a detrimental effect on the quality parameters and sensory attributes. It may cause deteriorative reactions, such as 
loss of nutrients, color changes, off-flavor development, and microbial activity. It has also a significant effect on the respiration rate and ethylene production in fruits and vegetable products. The elimination or even exclusion of $\mathrm{O}_{2}$ has been an aspect of significant effort in the preservation of food products. Passive barrier packaging materials, as for example, high barrier materials and multilayer systems, which contain ethylene-vinyl-alcohol copolymers or aluminum foil, may be used for the packaging of $\mathrm{O}_{2}$ sensitive foods [130], as well as high barrier nanocomposites [131]. However, the absolute elimination of $\mathrm{O}_{2}$ into the headspace or the dissolution of $\mathrm{O}_{2}$ on the food surface or $\mathrm{O}_{2}$ permeated into the package wall cannot be attained by passive methods. Therefore, $\mathrm{O}_{2}$ scavengers, also referred to as $\mathrm{O}_{2}$ absorbers, can be advantageous to retain food quality by decreasing food metabolism, reducing oxidative rancidity, inhibiting undesirable oxidation of labile pigments and vitamins, delaying enzymatic browning, controlling enzymatic discoloration, and inhibiting the growth of aerobic microorganisms [132-134]. $\mathrm{O}_{2}$ scavengers have been reported as the most commercially important type of active food packaging. $\mathrm{O}_{2}$ scavengers are based on compounds, such as powdered iron or ascorbic acid, the former being more widely applied. In absorbers, the absorption capacity and rate are constant, representing their two typical and primary parameters. Despite the well-documented absorption potential of commercial sachets, the absorption rate, a parameter of fundamental importance for food quality, has been evaluated in limited studies. The most commonly used $\mathrm{O}_{2}$ scavengers are small sachets containing various iron-based powders along with a series of catalysts that scavenge $\mathrm{O}_{2}$ within the food package and irreversibly transform it into a stable oxide [135]. Oxygen scavengers may be applied alone or combined with MAP. In the case that they are applied alone, MAP machinery will not be needed, and the packaging stage will be accelerated. However, the main amount of ambient $\mathrm{O}_{2}$ is removed by MAP in standard commercial practice, and the residual oxygen left inside the package is removed by a relatively small and inexpensive scavenger [136]. The Ageless ${ }^{\circledR}$ $\mathrm{O}_{2}$ absorber was introduced in 1977 by Mitsubishi Gas Company. This system consisted of reduced iron salts, activated by $\mathrm{H}_{2} \mathrm{O}$ and placed in a sealed gas-barrier package, where Fe oxidized to a ferric state. The reduced iron-containing sachets were applied with appropriate $\mathrm{O}_{2}$ scavengers to enable the preservation of the contained foods in large containers. Later on, Toppan Printing (Tokyo, Japan) launched an ascorbic-acid-based $\mathrm{O}_{2}$ scavenger. During the nineties, Toyo Seikan Kaisha Ltd., Tokyo, Japan (with Oxyguard ${ }^{\circledR}$ ), W.R. Grace and Company, Columbia, MD, USA (with Daraform ${ }^{\circledR} 6490$ and Cryovac ${ }^{\circledR}$ OS1000), and Multisorb Technologies Inc., New York, NY, USA (with FreshMax ${ }^{\circledR}$ ) provided the most updated $\mathrm{O}_{2}$ scavengers relevant with the current $\mathrm{O}_{2}$ absorber systems, such as OxySorbTM (Wholesale Group International Pty. Ltd., Australia) [137]. Charles et al. [138] reported that the application of $\mathrm{O}_{2}$ absorbers on packaging may extend the shelf life of tomatoes. By the application of a low-density polyethylene film in conjunction with an iron-based $\mathrm{O}_{2}$ absorber, the $\mathrm{CO}_{2}$ peak was suppressed. Additionally, oxygen absorbers have been applied for the inhibition of $\beta$-carotene oxidation in dried sweet potato flakes. The combined application of oxygen absorbers and flexible oxygen barrier films resulted in significant retention of $\beta$-carotene in sweet potato flakes during 210 days of storage [139]. Furthermore, the red flour beetle showed a $100 \%$ mortality rate in packaged sultana raisins stored at $15-30{ }^{\circ} \mathrm{C}$ for $9-45$ days. In the same study, the surface color was maintained by the application of an $\mathrm{O}_{2}$ absorber and storage temperature at $15{ }^{\circ} \mathrm{C}$ [140]. Oxygen absorbers hinder microorganisms in fruit and vegetable storage and additionally preserve the nutritional quality of food, such as vitamin concentration [137].

One of the crucial development steps in the fresh and minimally processed produce packaging sector is antimicrobial packaging systems, which are achieved by the incorporation of sachets or pads which contain volatile antimicrobial compounds, the application of antimicrobial and antioxidant packaging films and antimicrobial (edible or nonedible) coatings. Several alternative forms of antimicrobial compounds (chemical or natural, volatile or nonvolatile) may be either added into the packaging materials or directly applied onto the food surface with appropriate coating [141,142]. Three types of antimicrobial packaging 
have been reported for their applicability on fresh and minimally processed fruits and vegetable products, namely:

- Antimicrobial sachets: enclosure into packages of sachets that contain volatile antimicrobial agents

- Antimicrobial films: incorporation of volatile or nonvolatile antimicrobial compounds into the formulation of packaging films

- Antimicrobial edible coatings: direct application on the food surface of antimicrobial edible coatings or films. In this case, the main component of the coating may be a polymer with antimicrobial property (e.g., chitosan), or additional antimicrobial agents are added in the film-forming solution [6].

An antimicrobial sachet may be described as a pad that contains volatile antimicrobial agents, which is placed inside the food package to enable the gradual release of the antimicrobial and its interaction with the headspace in the package. The moisture concentration inside the package has been hypothesized as being the driving force for the release of the antimicrobial agent from the sachet system, and the released antimicrobial compounds inhibit the growth of microorganisms on the surface of the packaged fruits and vegetables [143]. Similar antimicrobial sachets containing alternative essential oils as antimicrobials have been reported as applicable for the inhibition of the growth of spoilage bacteria and pathogens in different products, including papaya, tomato and spinach leaves [69-71].

Antimicrobial film-forming materials are developed by incorporating the antimicrobial agents into a polymer matrix which allows their release onto the food surface to interact with the microflora. Zhang et al. [72] investigated the effect of a custom-made antimicrobial film by applying a coating containing sustained-release chlorine dioxide microcapsules on fresh mangos. According to a study reported by Ghaouth et al. [73], chitosan-coated tomatoes were adequately protected from Penicillium spp., Aspergillus spp., Rhizopus stolonifer, and Botrytis cinerea. Chitosan has been reported to provide appropriate control of fungal diseases, which may result in deterioration of fruit quality indices during storage [144]. Choulitoudi et al. [145] investigated the antioxidant effect of Satureja thymbra extracts, an ingredient rich in phenolic acids and flavonoids, after being sprayed on a non-edible, laminated packaging film for the prolongation of fried potato crisps' shelf life. The tested indices were peroxide values, volatile products, and oxygen consumption. Moreover, the application of the extracts, either in active packaging or as additives onto the potato crisps, was investigated, with the former exhibiting the most significant antioxidant effect. Edible coating or film is referred to as a thin layer of material used for coating or wrapping several food products in order to decrease the rate of quality deterioration and prolong their shelf life. Edible films may be produced separately and subsequently applied to the foods, while coatings are formed directly onto the food surface [146]. In general, appropriate barriers to moisture and gases (mainly $\mathrm{O}_{2}$ and $\mathrm{CO}_{2}$ for fresh produce), uniform coating, adequate adhesion to food surface, colorlessness, and tastelessness are the basic requirements for an edible packaging system $[147,148]$. It is possible to apply coatings in various ways, including dipping, spraying, falling, or brushing. Quadros et al. [74] investigated the effectiveness of edible coatings with fish protein hydrolysate on the quality indices and shelf life of cherry tomatoes. The microbial growth results indicated that the protein hydrolysate-based edible coatings showed significant bioactivity as they inhibited the proliferation of molds and yeasts. Ruiz-Martinez et al. [75] reported the enhancement of the postharvest quality of tomatoes by an edible coating functionalized with a Flourensia cernua extract. Sortino et al. [76] evaluated the effectiveness of an edible coating based on Aloe arborescens and a combined treatment of 1-methylcycyclopropene and edible coating to improve the quality and prolong the shelf life of the "Settembrina" peach. 


\subsection{Smart Labels for Fruits and Vegetables}

Smart packaging technology may provide crucial information regarding food quality, either indirectly (for example, Time Temperature Integrators) or directly (for example, freshness indicators) [149].

Freshness indicators may be referred to as appropriate devices that are incorporated into the sealed packaging of the food product and are intended to notify the end-user of the microbial and physicochemical changes that impact the quality level of the packaged food product. The interactions between the microbial metabolites and the indicators incorporated into the food package will visualize food quality in terms of microbial level $[129,150]$. Most of the proposed systems that have been developed up to now are based on the color changes of a label as a result of the microbial metabolism, which indicates that the packaged food may be no longer appropriate for consumption [151]. For fruits and vegetables, the state of freshness is commonly expressed within the context of ripeness. At a specific state of ripeness, it is often difficult to know when the fruit has entered the desired quality levels for the customer to use. For buyers, this condition often becomes an obstacle in understanding when the fruits should be purchased or consumed. The ripeSenseTM ( www.ripesense.co.nz, accessed on 19 February 2021) has launched a ripeness sensor that enables the elimination of this problem. The sensor responds to the aromas that are released from the ripening fruit. The sensor is initially red and switches to orange and then yellow. This sensor has been used on pears and may also be used on other stone fruits, such as kiwifruit, melon, mango, and avocado [152]. Furthermore, the volatile compounds emitted during the different stages of fruit ripeness were analyzed using e-noses and used to assess the ripeness of tomatoes [153]. A color indicator based on bromophenol blue placed on the food package has been designed, and preliminary tests have been carried out to evaluate the freshness of guava (Psidium guajava L.) samples by [154]. A freshness sensor has been developed by Kemiklioglu and Ozen [119], which works with the principle of measurement of ion concentration change occurring in fruits and vegetables.

A Time Temperature Integrator (TTI) is defined as an inexpensive, smart label that may show as easily measurable time- and temperature-dependent change, reflecting the time-temperature history of the product to which it has been attached [155]. The principle of TTI operation is a mechanical, chemical, electrochemical, enzymatic or microbiological irreversible change, which is mainly expressed as a visual response (e.g., mechanical deformation, color change, or movement). During the last thirty years, several alternative TTI systems have been developed; however, a limited number have reached the industrial prototype stage, and even fewer have found a commercial application [125]. The chronology of the development of TTI has been summarized by Taoukis [156]. TTIs have been reported as effective tools for quality and shelf-life monitoring of perishable foods, mainly meat and fish products, in the cold chain. For these food product categories, temperature plays a critical role in quality degradation and shelf life at any stage of the supply chain. In Bobelyn et al. [157], a feasibility study has been described with the aim to evaluate the potential of TTI application as indicators of the quality of horticultural products. In this study, mushroom (Agaricus bisporus Pilát) has been used as a case study. An appropriate enzymatic TTI (Vitsab A.B., Malmö, Sweden) has been used for quality monitoring of mushrooms at constant and variable temperature conditions.

\section{Conclusions}

The demand for fresh, nutritious, and convenient food by consumers has recently shown a constant rise. New product development and the diversification of fruit- and vegetable-based food products have supported this trend. Whilst addressing the consumer demand for novel, nutritious, and affordable products, food producers must consider also the requirement for food safety assurance and shelf-life extension for the developed products. A scientific challenge for the food sector is to investigate the potential of shelf-life extension and the development of appropriate shelf-life predictive models [67]. In general, minimal processing has shown the potential to further extend the shelf life of fruits and 
vegetables by the combined application of different preservative hurdles, as for example low temperature, natural or synthetic antimicrobials and antioxidants, $\mathrm{a}_{\mathrm{w}}, \mathrm{pH}$, and high pressure with packaging methods, such as modified atmospheres and active packaging. Future research should be focused on the development of mild processing techniques, in the context of hurdle technology, that retain the fresh-like characteristics while at the same time extend the shelf life of the final products without jeopardizing their safety and integrity. Additionally, the introduction of optimal active and smart packaging methods by the incorporation of alternative active compounds or active and smart functionalities in a new, combined system may also contribute to this objective.

Author Contributions: Conceptualization, M.C.G. and T.N.T.; investigation, M.C.G. and T.N.T.; Writing-Original draft preparation, M.C.G. and T.N.T.; Writing-Review and Editing, M.C.G. and T.N.T. All authors have read and agreed to the published version of the manuscript.

Funding: This research received no external funding.

Conflicts of Interest: The authors declare no conflict of interest.

\section{References}

1. WHO. Diet, Nutrition and the Prevention of Chronic Disease; World Health Organization Technical Report Series 797; World Health Organization: Geneva, Switzerland, 1990.

2. Cox, D.N.; Anderson, A.S.; McKellar, S.; Reynolds, J.; Lean, M.E.J.; Mela, D.J. Vegetables and fruits: Barriers and opportunities for greater consumption. Nutr. Food Sci. 1996, 96, 44-47. [CrossRef]

3. Ragaert, P.; Verbeke, W.; Devlieghere, F.; Debevere, J. Consumer perception and choice of minimally processed vegetables and packaged fruits. Food Qual. Prefer. 2004, 15, 259-270. [CrossRef]

4. Oms-Oliu, G.; Rojas-Graü, M.A.; González, L.A.; Varela, P.; Soliva-Fortuny, R.; Hernando, M.I.H.; Munuera, I.P.; Fiszman, S.; Martín-Belloso, O. Recent approaches using chemical treatments to preserve quality of fresh-cut fruit: A review. Postharvest Biol. Technol. 2010, 57, 139-148. [CrossRef]

5. Thunberg, R.L.; Tran, T.T.; Bennett, R.W.; Matthews, R.N.; Belay, N. Microbial evaluation of selected fresh produce obtained at retail markets. J. Food Prot. 2002, 65, 677-682. [CrossRef] [PubMed]

6. Jung, J.; Zhao, Y. Antimicrobial packaging for fresh and minimally processed fruits and vegetables. In Antimicrobial Food Packaging; Barros-Velázquez, J., Ed.; Academic Press: Cambridge, MA, USA, 2016; pp. 243-256.

7. Erkmen, O.; Bozoglu, T.F. Food Preservation by Combination of Techniques (Hurdle Technology). 1st Edition. In Food Microbiology: Principles into Practice; John Wiley \& Sons Ltd.: Hoboken, NJ, USA, 2016; pp. 166-179.

8. Leistner, L. Basic aspects of food preservation by hurdle technology. Int. J. Food Microbiol. 2000, 55, 181-186. [CrossRef]

9. Leistner, L. Hurdle Technology in the Design of Minimally Processed Foods. In Minimally Processed Fruits and Vegetables: Fundamentals and Applications; Alzamora, S.M., Lopez-Malo, A., Tapia, M.S., Eds.; Aspen Publishers Inc.: New York, NY, USA, 2000; pp. 13-28.

10. Leistner, L.; Gorris, L.G.M. Food preservation by hurdle technology. Trends Food Sci. Technol. 1995, 6, 41-46. [CrossRef]

11. Singh, S.; Shalini, R. Effect of Hurdle Technology in Food Preservation: A Review. Crit. Rev. Food Sci. Nutr. 2016, 56, 641-649. [CrossRef] [PubMed]

12. Scetar, M.; Kurek, M.; Galic, K. Trends in fruit and vegetable packaging-A Review. Croat. Food Technol. Biotechnol. Nutr. 2010, 5, 69-86.

13. Jalali, A.; Seiiedlou, S.; Linke, M.; Mahajan, P. A comprehensive simulation program for modified atmosphere and humidity packaging (MAHP) of fresh fruits and vegetables. J. Food Eng. 2017, 206, 88-97. [CrossRef]

14. Sucheta Singla, G.; Chaturvedi, K.; Sandhu, P.P. Status and recent trends in fresh-cut fruits and vegetables. In Fresh-Cut Fruits and Vegetables; Siddiqui, M.W., Ed.; Academic Press: Cambridge, MA, USA, 2020; pp. 17-49.

15. Rastogi, N.K.; Raghavarao, K.S.M.S.; Niranjan, K. Recent Developments in Osmotic Dehydration. In Emerging Technologies for Food Processing, 2nd ed.; Sun, D.-W., Ed.; Academic Press: San Diego, CA, USA, 2014; pp. 181-212.

16. Ragaert, P.; Jacxsens, L.; Vandekinderen, I.; Baert, L.; Devlieghere, F. Microbiological and Safety Aspects of Fresh-Cut Fruits and Vegetables. In Advances in Fresh-Cut Fruits and Vegetables Processing; Martin-Belloso, O., Soliva-Fortuny, R., Eds.; CRC Press: New York, NY, USA, 2011; pp. 53-86.

17. Montero-Calderón, M.; del Milagro Cerdas-Araya, M. Fruits and Vegetables for the Fresh-Cut Processing Industry. In Advances in Fresh-Cut Fruits and Vegetables Processing; Martin-Belloso, O., Soliva-Fortuny, R., Eds.; CRC Press: New York, NY, USA, 2011; pp. 186-205.

18. Baldwin, E.A.; Bai, J. Physiology of Fresh-Cut Fruits and Vegetables. In Advances in Fresh-Cut Fruits and Vegetables Processing; Martin-Belloso, O., Soliva-Fortuny, R., Eds.; CRC Press: New York, NY, USA, 2011; pp. 87-104.

19. Ben-Fadhel, Y.; Cingolani, M.C.; Li, L.; Chazot, G.; Salmieri, S.; Horak, C.; Lacroix, M. Effect of $\gamma$-irradiation and the use of combined treatments with edible bioactive coating on carrot preservation. Food Packag. Shelf Life 2021, 28, 100635. [CrossRef] 
20. Kwon, S.-A.; Song, W.-J.; Kang, D.-H. Combination effect of saturated or superheated steam and lactic acid on the inactivation of Escherichia coli O157:H7, Salmonella Typhimurium and Listeria monocytogenes on cantaloupe surfaces. Food Microbiol. 2019, 82, 342-348. [CrossRef] [PubMed]

21. Massey, L.M.; Hettiarachchy, N.S.; Horax, R.; Rayaprolu, S.J.; Kumar-Phillips, G.; Martin, E.M.; Ricke, S.C. Efficacy of organic acid electrostatic spray for decontaminating Salmonella on cantaloupe cubes and cherry tomatoes. J. Food Process Preserv. 2018, 42, e13748. [CrossRef]

22. Zou, Y.; Yu, Y.; Cheng, L.; Li, L.; Zou, B.; Wu, J.; Zhou, W.; Li, J.; Xu, Y. Effects of curcumin-based photodynamic treatment on quality attributes of fresh-cut pineapple. LWT Food Sci. Technol. 2021, 141, 110902. [CrossRef]

23. Rodríguez-Arzuaga, M.; Salsi, M.S.; Piagentini, A.M. Storage quality of fresh-cut apples treated with yerba mate (Ilex paraguariensis). J. Food Sci. Technol. 2021, 58, 186-196. [CrossRef]

24. Avalos-Llano, K.R.; Molina, R.S.; Sgroppo, S.C. UV-C Treatment Applied Alone or Combined with Orange Juice to Improve the Bioactive Properties, Microbiological, and Sensory Quality of Fresh-Cut Strawberries. Food Bioprocess Technol. 2020, 13, 1528-1543. [CrossRef]

25. Solomos, T. Aspects of the Biology and Physics Underlying Modified Atmosphere Packaging. In Minimally Processed Refrigerated Fruits and Vegetables; Yildiz, F., Wiley, R.C., Eds.; Springer: New York, NY, USA, 2017; pp. 17-53.

26. Yildiz, F. Initial Preparation, Handling, and Distribution of Minimally Processed Refrigerated Fruits and Vegetables. In Minimally Processed Refrigerated Fruits and Vegetables; Yildiz, F., Wiley, R.C., Eds.; Springer: New York, NY, USA, 2017 ; pp. 53-93.

27. Temiz, A.; Ayhan, D.K. Enzymes in Minimally Processed Fruits and Vegetables. In Minimally Processed Refrigerated Fruits and Vegetables; Yildiz, F., Wiley, R.C., Eds.; Springer: New York, NY, USA, 2017; pp. 93-153.

28. Varoquaux, P.; Wiley, R.C. Biological and Biochemical Changes in Minimally Processed Refrigerated Fruits and Vegetables. In Minimally Processed Refrigerated Fruits and Vegetables; Yildiz, F., Wiley, R.C., Eds.; Springer: New York, NY, USA, 2017; pp. 153-186.

29. Wiley, R.C. Preservation Methods for Minimally Processed Refrigerated Fruits and Vegetables. In Minimally Processed Refrigerated Fruits and Vegetables; Yildiz, F., Wiley, R.C., Eds.; Springer: New York, NY, USA, 2017; pp. 187-238.

30. Bhatia, K.; Asrey, R. Minimal processing of pomegranates (Punica granatum L.)—A review on processing, quality, and shelf life. J. Food Process Preserv. 2019, 43, e14281. [CrossRef]

31. Massolo, J.F.; González Forte, L.; Concellón, A.; Viña, S.Z.; Vicente, A.R. Effects of ethylene and 1-MCP on quality maintenance of fresh cut celery. Postharvest Biol. Technol. 2019, 148, 176-183. [CrossRef]

32. Paulsen, E.; Barrios, S.; Baenas, N.; Moreno, D.A.; Heinzen, H.; Lema, P. Effect of temperature on glucosinolate content and shelf life of ready-to-eat broccoli florets packaged in passive modified atmosphere. Postharvest Biol. Technol. 2018, 138, 125-133. [CrossRef]

33. Lwin, W.W.; Pongprasert, N.; Boonyaritthongchai, P.; Wongs-Aree, C.; Srilaong, V. Synergistic effect of vacuum packaging and cold shock reduce lignification of asparagus. J. Food Biochem. 2020, 44, e13479. [CrossRef]

34. Xanthopoulos, G.T.; Athanasiou, A.A.; Lentzou, D.I.; Boudouvis, A.G.; Lambrinos, G.P. Modelling of transpiration rate of grape tomatoes. Semi-empirical and analytical approach. Biosyst. Eng. 2014, 124, 16-23. [CrossRef]

35. Aindongo, W.V.; Caleb, O.J.; Mahajan, P.V.; Manley, M.; Opara, U.L. Effects of storage conditions on transpiration rate of pomegranate aril-sacs and arils. S. Afr. J. Plant Soil 2014, 31, 7-11. [CrossRef]

36. Zhao, H.; Fan, Z.; Wu, J.; Zhu, S. Effects of pre-treatment with S-nitrosoglutathione-chitosan nanoparticles on quality and antioxidant systems of fresh-cut apple slices. LWT Food Sci. Technol. 2021, 139, 110565. [CrossRef]

37. Cofelice, M.; Lopez, F.; Cuomo, F. Quality Control of Fresh-Cut Apples after Coating Application. Foods 2019, 8, 189. [CrossRef] [PubMed]

38. González-Buesa, J.; Page, N.; Kaminski, C.; Ryser, E.T.; Beaudry, R.; Almenar, E. Effect of non-conventional atmospheres and bio-based packaging on the quality and safety of Listeria monocytogenes-inoculated fresh-cut celery (Apium graveolens L.) during storage. Postharvest Biol. Technol. 2014, 93, 29-37. [CrossRef]

39. Kumar, N.; Kaur, P.; Devgan, K.; Attkan, A.K. Shelf life prolongation of cherry tomato using magnesium hydroxide reinforced bio-nanocomposite and conventional plastic films. J. Food Process Preserv. 2020, 44, e14379. [CrossRef]

40. Drobek, M.; Frąc, M.; Zdunek, A.; Cybulska, J. The Effect of Cultivation Method of Strawberry (Fragaria x ananassa Duch.) cv. Honeoye on Structure and Degradation Dynamics of Pectin during Cold Storage. Molecules 2020, 25, 4325. [CrossRef] [PubMed]

41. Retta, M.A.; Verlinden, B.; Verboven, P.; Nicolaï, B. Texture-microstructure relationship of leafy vegetables during postharvest storage. Acta Hortic. 2019, 1256, 169-178. [CrossRef]

42. Wang, H.; Fang, X.-M.; Sutar, P.P.; Meng, J.-S.; Wang, J.; Yu, X.-L.; Xiao, H.-W. Effects of vacuum-steam pulsed blanching on drying kinetics, colour, phytochemical contents, antioxidant capacity of carrot and the mechanism of carrot quality changes revealed by texture, microstructure and ultrastructure. Food Chem. 2021, 338, 127799. [CrossRef]

43. Parreidt, T.; Schmid, M.; Müller, K. Effect of Dipping and Vacuum Impregnation Coating Techniques with Alginate Based Coating on Physical Quality Parameters of Cantaloupe Melon. J. Food Sci. 2018, 83, 929-936. [CrossRef]

44. Barrett, D.M.; Beaulieu, J.C.; Shewfelt, R. Color, Flavor, Texture, and Nutritional Quality of Fresh-Cut Fruits and Vegetables: Desirable Levels, Instrumental and Sensory Measurement, and the Effects of Processing. Crit. Rev. Food Sci. Nutr. 2010, 50, 369-389. [CrossRef]

45. Kader, A.A.; Barrett, D.M. Classification, composition of fruits, and postharvest maintenance of quality. In Processing Fruits; Barrett, D.M., Somogyi, L., Ramaswamy, H., Eds.; CRC Press: Boca Raton, FL, USA, 2004; pp. 3-22. 
46. Kader, A.A. Prevention of ripening in fruits by use of controlled atmospheres. Food Technol. 1980, 34, 45.

47. Harris, L.J.; Farber, J.N.; Beuchat, L.R.; Parish, M.E.; Suslow, T.V.; Garrett, E.H.; Busta, F.F. Outbreaks associated with fresh produce: Incidence, growth, and survival of pathogens in fresh and fresh-cut produce. Compr. Rev. Food Sci. Food Saf. 2003, 2, 78-141. [CrossRef]

48. Wiley, R.C.; Yildiz, F. Introduction to Minimally Processed Refrigerated (MPR) Fruits and Vegetables. In Minimally Processed Refrigerated Fruits and Vegetables; Yildiz, F., Wiley, R.C., Eds.; Springer: New York, NY, USA, 2017; pp. 3-17.

49. Dabas, K.; Khan, K.A. Use of hurdle technology in processing of fruits and vegetables. In Processing of Fruits and Vegetables-From Farm to Fork; Khan, K.A., Megh, R., Goyal, P.E., Kalne, A.A., Eds.; Apple Academic Press: Oakville, ON, Canada, 2020; pp. 113-138.

50. Allende, A.; Tomás-Barberán, F.A.; Gil, M.I. Minimal processing for healthy traditional foods. Trends Food Sci. Technol. 2006, 17, 513-519. [CrossRef]

51. Gil, M.I.; Allende, A.; Selma, M.V. Treatments to Ensure Safety of Fresh-Cut Fruits and Vegetables. In Advances in Fresh-Cut Fruits and Vegetables Processing; Martin-Belloso, O., Soliva-Fortuny, R., Eds.; CRC Press: New York, NY, USA, 2011 ; pp. $211-224$.

52. Tapia, M.S.; Alzamora, S.M.; Chanes, J.W.; Gould, G. Combination of preservation factors applied to minimal processing of foods. Crit. Rev. Food Sci. Nutr. 1996, 36, 629-659. [CrossRef]

53. Allende, A.; Artes, F. UV-C radiation as a novel technique for keeping quality of fresh processed "Lollo Rosso" lettuce. Food Res. Int. 2003, 36, 739-746. [CrossRef]

54. Koh, P.C.; Noranizan, M.A.; Karim, R.; Nur Hanani, Z.A.; Lasik-Kurdyś, M. Combination of alginate coating and repetitive pulsed light for shelf life extension of fresh-cut cantaloupe (Cucumis melo L. reticulatus cv. Glamour). J. Food Process. Preserv. 2018, 42, e13786. [CrossRef]

55. Dermesonlouoglou, E.K.; Andreou, V.; Alexandrakis, Z.; Katsaros, G.J.; Giannakourou, M.C.; Taoukis, P.S. The hurdle effect of osmotic pretreatment and high-pressure cold pasteurisation on the shelf-life extension of fresh-cut tomatoes. Int. J. Food Sci. Technol. 2017, 52, 916-926. [CrossRef]

56. Moreira, M.R.; Álvarez, M.V.; Martín-Belloso, O.; Soliva-Fortuny, R. Effects of pulsed light treatments and pectin edible coatings on the quality of fresh-cut apples: A hurdle technology approach. J. Sci. Food Agric. 2017, 97, 261-268. [CrossRef]

57. Luo, K.; Oh, D.-H. Inactivation kinetics of Listeria monocytogenes and Salmonella enterica serovar Typhimurium on fresh-cut bell pepper treated with slightly acidic electrolyzed water combined with ultrasound and mild heat. Food Microbiol. 2016, 53, 165-171. [CrossRef]

58. Jang, J.-H.; Moon, K.-D. Inhibition of polyphenol oxidase and peroxidase activities on fresh-cut apple by simultaneous treatment of ultrasound and ascorbic acid. Food Chem. 2011, 124, 444-449. [CrossRef]

59. Dermesonlouoglou, E.K.; Angelikaki, F.; Giannakourou, M.C.; Katsaros, G.J.; Taoukis, P.S. Minimally Processed Fresh-Cut Peach and Apricot Snacks of Extended Shelf-Life by Combined Osmotic and High Pressure Processing. Food Bioprocess Technol. 2019, 12, 371-386. [CrossRef]

60. Kumar, P.; Sethi, S.; Sharma, R.R.; Singh, S.; Varghese, E. Improving the shelf life of fresh-cut 'Royal Delicious' apple with edible coatings and anti-browning agents. J. Food Sci. Technol. 2018, 55, 3767-3778. [CrossRef] [PubMed]

61. Son, J.; Hyun, J.-E.; Lee, J.-W.; Lee, S.-Y.; Moon, B. Combined application of antibrowning, heat treatment and modified-atmosphere packaging to extend the shelf life of fresh-cut lotus root. J. Food Sci. 2015, 80, C1178-C1187. [CrossRef]

62. Putnik, P.; Bursać Kovačević, D.; Herceg, K.; Levaj, B. Influence of antibrowning solutions, air exposure, and ultrasound on color changes in fresh-cut apples during storage. J. Food Process. Preserv. 2017, 41, e13288. [CrossRef]

63. Dermesonlouoglou, E.K.; Bimpilas, A.; Andreou, V.; Katsaros, G.J.; Giannakourou, M.C.; Taoukis, P.S. Process Optimization and Kinetic Modeling of Quality of Fresh-Cut Strawberry Cubes Pretreated by High Pressure and Osmosis. J. Food Process. Preserv. 2017, 41, e13137. [CrossRef]

64. Gutiérrez, D.; Chaves, A.; Rodriguez, S.D. Use of UV-C and Gaseous Ozone as Sanitizing Agents for Keeping the Quality of Fresh-Cut Rocket (Eruca sativa mill). J. Food Process. Preserv. 2017, 41, e12968. [CrossRef]

65. Pittia, P.; Nicoli, M.C.; Comi, G.; Massini, R. Shelf-life extension of fresh-like ready-to-use pear cubes. J. Sci. Food Agric. 1999, 79, 955-960. [CrossRef]

66. Tsironi, T.; Dermesonlouoglou, E.; Giannoglou, M.; Gogou, E.; Katsaros, G.; Taoukis, P. Shelf life models for ready-to-eat fresh cut salads: Testing in real cold chain. Int. J. Food Microbiol. 2016, 240, 131-140. [CrossRef]

67. Dermesonlouoglou, E.; Fileri, K.; Orfanoudaki, A.; Tsevdou, M.; Tsironi, T.; Taoukis, P. Modelling the microbial spoilage and quality decay of pre-packed dandelion leaves as a function of temperature. J. Food Eng. 2016, 184, 21-30. [CrossRef]

68. Mistriotis, A.; Briassoulis, D.; Giannoulis, A.; D'Aquino, S. Design of biodegradable bio-based equilibrium modified atmosphere packaging (EMAP) for fresh fruits and vegetables by using micro-perforated poly-lactic acid (PLA) films. Postharvest Biol. Technol. 2016, 111, 380-389. [CrossRef]

69. Ayala-Zavala, J.F.; González-Aguilar, G.A. Optimizing the use of garlic oil as antimicrobial agent on fresh-cut tomato through a controlled release system. J. Food Sci. 2010, 75, M398-M405. [CrossRef] [PubMed]

70. Espitia, P.J.P.; Soares, N.D.F.F.; Botti, L.C.M.; Melo, N.R.D.; Pereira, O.L.; Silva, W.A.D. Assessment of the efficiency of essential oils in the preservation of postharvest papaya in an antimicrobial packaging system. Braz. J. Food Technol. 2012, 15, 333-342. [CrossRef] 
71. Seo, H.-S.; Bang, J.; Kim, H.; Beuchat, L.R.; Cho, S.Y.; Ryu, J.-H. Development of an antimicrobial sachet containing encapsulated allyl isothiocyanate to inactivate Escherichia coli O157:H7 on spinach leaves. Int. J. Food Microbiol. 2012, 159, 136-143. [CrossRef] [PubMed]

72. Zhang, B.; Huang, C.; Zhang, L.; Wang, J.; Huang, X.; Zhao, Y.; Liu, Y.; Li, C. Application of chlorine dioxide microcapsule sustained-release antibacterial films for preservation of mangos. J. Food Sci. Technol. 2019, 56, 1095-1103. [CrossRef] [PubMed]

73. Ghaouth, A.; Ponnampalam, R.; Castaigne, F.; Arul, J. Chitosan coating to extend the storage life of tomatoes. Hortscience 1992, 27, 1016-1018. [CrossRef]

74. Quadros, C.; Lima, K.O.; Bueno, C.H.L.; dos Santos Fogaca, F.H.; da Rocha, M.; Prentice, C. Effect of the edible coating with protein hydrolysate on cherry tomatoes shelf life. J. Food Process. Preserv. 2020, 44, e14760.

75. Ruiz-Martínez, J.; Aguirre-Joya, J.A.; Rojas, R.; Vicente, A.; Aguilar-González, M.A.; Rodríguez-Herrera, R.; Alvarez-Perez, O.B.; Torres-León, C.; Aguilar, C.N. Candelilla Wax Edible Coating with Flourensia cernua Bioactives to Prolong the Quality of Tomato Fruits. Foods 2020, 9, 1303. [CrossRef]

76. Sortino, G.; Saletta, F.; Puccio, S.; Scuderi, D.; Allegra, A.; Inglese, P.; Farina, V. Extending the Shelf Life of White Peach Fruit with 1-Methylcyclopropene and Aloe arborescens Edible Coating. Agriculture 2020, 10, 151. [CrossRef]

77. Rux, G.; Efe, E.; Ulrichs, C.; Huyskens-Keil, S.; Hassenberg, K.; Herppich, W.B. Effects of Pre-Processing Hot-Water Treatment on Aroma Relevant VOCs of Fresh-Cut Apple Slices Stored in Sugar Syrup. Foods 2020, 9, 78. [CrossRef]

78. Chiabrando, V.; Peano, C.; Giacalone, G. Influence of hot water treatments on postharvest physicochemical characteristics of Hayward and Jintao kiwifruit slices. J. Food Process Preserv. 2018, 42, e13563. [CrossRef]

79. Herppich, W.B.; Maggioni, M.; Huyskens-Keil, S.; Kabelitz, T.; Hassenberg, K. Optimization of Short-Term Hot-Water Treatment of Apples for Fruit Salad Production by Non-Invasive Chlorophyll-Fluorescence Imaging. Foods 2020, 9, 820. [CrossRef]

80. Kabelitz, T.; Hassenberg, K. Control of apple surface microflora for fresh-cut produce by post-harvest hot-water treatment. LWT Food Sci. Technol. 2018, 98, 492-499. [CrossRef]

81. Pareek, S. Novel Postharvest Treatments of Fresh Produce, 1st ed.; CRC Press: Boca Raton, FL, USA, 2018.

82. Sivakumar, D.; Fallik, E. Influence of Heat Treatments on Quality Retention of Fresh and Fresh-Cut Produce. Food Rev. Int. 2013, 29, 294-320. [CrossRef]

83. Paillart, M.J.M.; Otma, E.C.; Woltering, E.J. Effect of mild heat-shock treatments on pink discoloration and physiological parameters in fresh-cut iceberg lettuce. LWT Food Sci. Technol. 2017, 85, 456-459. [CrossRef]

84. Shrestha, L.; Kulig, B.; Moscetti, R.; Massantini, R.; Pawelzik, E.; Hensel, O.; Sturm, B. Optimisation of Physical and Chemical Treatments to Control Browning Development and Enzymatic Activity on Fresh-cut Apple Slices. Foods 2020, 9, 76. [CrossRef]

85. Garrido, Y.; Tudela, J.A.; Gil, M.I. Comparison of industrial precooling systems for minimally processed baby spinach. Postharvest Biol. Technol. 2015, 102, 1-8. [CrossRef]

86. Kang, C.; Sloniker, N.; Ryser, N.T. Use of a Novel Sanitizer To Inactivate Salmonella Typhimurium and Spoilage Microorganisms during Flume Washing of Diced Tomatoes. J. Food Prot. 2020, 83, 2158-2166. [CrossRef]

87. Sethi, S.; Nayak, S.L.; Joshi, A.; Sharma, R.R. Sanitizers for fresh-cut fruits and vegetables. In Fresh-Cut Fruits and Vegetables; Siddiqui, M.W., Ed.; Academic Press: Cambridge, MA, USA, 2020; pp. 99-119.

88. Chen, X.; Hung, Y.-C. Development of a Chlorine Dosing Strategy for Fresh Produce Washing Process to Maintain Microbial Food Safety and Minimize Residual Chlorine. J. Food Sci. 2018, 83, 1701-1706. [CrossRef] [PubMed]

89. Banach, J.L.; van Overbeek, L.S.; Nierop Groot, M.N.; van der Zouwen, P.S.; van der Fels-Klerx, H.J. Efficacy of chlorine dioxide on Escherichia coli inactivation during pilot-scale fresh-cut lettuce processing. Int. J. Food Microbiol. 2018, 269, 128-136. [CrossRef]

90. Wengert, S.L.; Aw, T.G.; Ryser, E.T.; Rose, J.B. Postharvest Reduction of Coliphage MS2 from Romaine Lettuce during Simulated Commercial Processing with and without a Chlorine-Based Sanitizer. J. Food Prot. 2017, 80, 220-224. [CrossRef] [PubMed]

91. Bari, M.L.; Ukuku, D.O.; Kawasaki, T.; Inatsu, Y.; Isshiki, K.; Kawamoto, S. Combined Efficacy of Nisin and Pediocin with Sodium Lactate, Citric Acid, Phytic Acid, and Potassium Sorbate and EDTA in Reducing the Listeria monocytogenes Population of Inoculated Fresh-Cut Produce. J. Food Prot. 2005, 68, 1381-1387. [CrossRef] [PubMed]

92. Gurtler, J.B.; Fan, X.; Jin, T.; Niemira, B.A. Influence of Antimicrobial Agents on the Thermal Sensitivity of Foodborne Pathogens: A Review. J. Food Prot. 2019, 82, 628-644. [CrossRef]

93. Medina, M.S.; Tudela, J.A.; Marín, A.; Allende, A.; Gil, M.I. Short postharvest storage under low relative humidity improves quality and shelf life of minimally processed baby spinach (Spinacia oleracea L.). Postharvest Biol. Technol. 2012, 67, 1-9. [CrossRef]

94. Leneveu-Jenvrin, C.; Charles, F.; Barba, F.J.; Remize, F. Role of biological control agents and physical treatments in maintaining the quality of fresh and minimally-processed fruit and vegetables. Crit. Rev. Food Sci. Nutr. 2020, 60, 2837-2855. [CrossRef]

95. Sagong, H.G.; Lee, S.Y.; Chang, P.S.; Heu, S.; Ryu, S.; Choi, Y.J.; Kang, D.H. Combined effect of ultrasound and organic acids to reduce Escherichia coli O157: H7, Salmonella typhimurium, and Listeria monocytogenes on organic fresh lettuce. Int. J. Food Microbiol. 2011, 145, 287-292. [CrossRef] [PubMed]

96. Al-Tayyar, N.A.; Youssef, A.M.; Al-Hindi, R.R. Edible coatings and antimicrobial nanoemulsions for enhancing shelf life and reducing foodborne pathogens of fruits and vegetables: A review. Sustain. Mater. Technol. 2020, 26, e00215.

97. Alzamora, S.M.; López-Malo, A.; Guerrero, S.N.; Tapia, M.S. The Hurdle Concept in Fruit Processing. In Fruit Preservation: Novel and Conventional Technologies; Rosenthal, A., Deliza, R., Welti-Chanes, J., Barbosa-Cánovas, G.V., Eds.; Springer: New York, NY, USA, 2018; pp. 93-126. 
98. De Corato, U. Improving the shelf-life and quality of fresh and minimally-processed fruits and vegetables for a modern food industry: A comprehensive critical review from the traditional technologies into the most promising advancements. Crit. Rev. Food Sci. Nutr. 2020, 60, 940-975. [CrossRef]

99. Hu, X.; Ma, T.; Ao, L.; Kang, H.; Hu, X.; Song, Y.; Liao, X. Effect of high hydrostatic pressure processing on textural properties and microstructural characterization of fresh-cut pumpkin (Cucurbita pepo). J. Food Process Eng. 2020, 43, e13379. [CrossRef]

100. Fan, X.; Wang, W. Quality of fresh and fresh-cut produce impacted by nonthermal physical technologies intended to enhance microbial safety. Crit. Rev. Food Sci. Nutr. 2020. [CrossRef] [PubMed]

101. Dellarosa, N.; Tappi, S.; Ragni, L.; Laghi, L.; Rocculi, P.; Dalla Rosa, M. Metabolic response of fresh-cut apples induced by pulsed electric fields. Innov. Food Sci. Emerg. Technol. 2016, 38, 356-364. [CrossRef]

102. Shayanfar, S.; Chauhan, O.P.; Toepfl, S.; Heinz, V. Effect of non-thermal hurdles in extending shelf life of cut apples. J. Food Sci. Technol. 2014, 51, 4033-4039. [CrossRef]

103. Graça, A.; Santo, D.; Pires-Cabral, P.; Quintas, C. The effect of UV-C and electrolyzed water on yeasts on fresh-cut apple at $4{ }^{\circ} \mathrm{C}$. J. Food Eng. 2020, 282, 110034. [CrossRef]

104. Santo, D.; Graça, A.; Nunes, C.; Quintas, C. Escherichia coli and Cronobacter sakazakii in 'Tommy Atkins' minimally processed mangos: Survival, growth and effect of UV-C and electrolyzed water. Food Microbiol. 2018, 70, 49-54. [CrossRef] [PubMed]

105. Aslam, R.; Alam, M.S.; Saeed, P.A. Sanitization Potential of Ozone and Its Role in Postharvest Quality Management of Fruits and Vegetables. Food Eng. Rev. 2020, 12, 48-67. [CrossRef]

106. Bhavya, M.L.; Umesh Hebbar, H. Pulsed light processing of foods for microbial safety. Food Qual. Saf. 2017, 1, 187-202. [CrossRef]

107. Perni, S.; Liu, D.; Shama, G.; Kong, M. Cold Atmospheric Plasma Decontamination of the Pericarps of Fruit. J. Food Prot. 2008, 71, 302-308. [CrossRef] [PubMed]

108. Schnabel, U.; Handorf, O.; Stachowiak, J.; Boehm, D.; Weit, C.; Weihe, T.; Schäfer, J.; Below, H.; Bourke, P.; Ehlbeck, J. PlasmaFunctionalized Water: From Bench to Prototype for Fresh-Cut Lettuce. Food Eng. Rev. 2021, 13, 115-135. [CrossRef]

109. Valverde, M.T.; Marın-Iniesta, F.; Calvo, L. Inactivation of Saccharomyces cerevisiae in conference pear with high pressure carbon dioxide and effects on pear quality. J. Food Eng. 2010, 98, 421-428. [CrossRef]

110. Calvo, L.; Torres, E. Microbial inactivation of paprika using high-pressure $\mathrm{CO}_{2}$. J. Supercrit. Fluids 2010, 52, 134-141. [CrossRef]

111. Pinela, J.; Ferreira, I.C.F.R. Nonthermal physical technologies to decontaminate and extend the shelf-life of fruits and vegetables: Trends aiming at quality and safety. Crit. Rev. Food Sci. Nutr. 2017, 57, 2095-2111. [CrossRef]

112. Venturi, F.; Bartolini, S.; Sanmartin, C.; Orlando, M.; Taglieri, I.; Macaluso, M.; Lucchesini, M.; Trivellini, A.; Zinnai, A.; Mensuali, A. Potato Peels as a Source of Novel Green Extracts Suitable as Antioxidant Additives for Fresh-Cut Fruits. Appl. Sci. 2019, 9, 2431. [CrossRef]

113. Badr, A.N.; Gromadzka, K.; Shehata, M.G.; Stuper-Szablewska, K.; Drzewiecka, K.; Abdel-Razek, A.G.; Youssef, M.M. Encapsulated Bioactive Ingredients of grape by-products applicate in fresh-cut fruit and juices diminished the ochratoxins. J. Food Process Preserv. 2021, 45, e15112. [CrossRef]

114. Lee, C.H.; Kang, J.-H.; Woo, H.J.; Song, K.B. Combined treatment of nut by-product extracts and peracetic acid against Listeria monocytogenes on red mustard and kale leaves. LWT Food Sci. Technol. 2020, 129, 109608. [CrossRef]

115. Ma, L.; Zhang, M.; Bhandari, B.; Gao, Z. Recent developments in novel shelf life extension technologies of fresh-cut fruits and vegetables. Trends Food Sci. Technol. 2020, 64, 23-38. [CrossRef]

116. Palekar, M.P.; Matthew Taylor, T.; Maxim, J.E.; Castillo, A. Reduction of Salmonella enterica serotype Poona and background microbiota on fresh-cut cantaloupe by electron beam irradiation. Int. J. Food Microbiol. 2015, 202, 66-72. [CrossRef]

117. Kim, J.; Moreira, R.; Castell-Perez, E. Simulation of pathogen inactivation in whole and fresh-cut cantaloupe (Cucumis melo) using electron beam treatment. J. Food Eng. 2010, 97, 425-433. [CrossRef]

118. Brocklehurst, T.F.; Zaman-Wong, C.M.; Lund, B.M. A note on the microbiology of re-tail packs of prepared salad vegetables. J. Appl. Bacteriol. 1987, 63, 409-415.

119. Kemiklioglu, E.; Ozen, O. Design of a sensor to detect fruit freshness. Int. J. Sci. Technol. Res. 2018, 4, 1-6.

120. Dial, L.A.; Musher-Eizenman, D.R. Power of packaging: Evaluations of packaged fruits and vegetables by school-age children in the U.S. Apetite 2020, 148, 104591. [CrossRef] [PubMed]

121. Song, Y.; Vorsa, N.; Yam, K.L. Modeling respiration-transpiration in a modified atmosphere packaging system containing blueberry. J. Food Eng. 2002, 53, 103-109. [CrossRef]

122. Sandhya. Review: Modified atmosphere packaging of fresh produce: Current status and future needs. LWT Food Sci. Technol. 2010, 43, 381-392. [CrossRef]

123. Lee, L.; Arul, J.; Lencki, R.; Castaigne, F. A review on modified atmosphere packaging and preservation of fresh fruits and vegetables: Physiological basis and practical aspects—Part 2. Packag. Technol. Sci. 1996, 9, 1-17. [CrossRef]

124. Smolander, M. The use of freshness indicators in packaging. In Novel Food Packaging Techniques; Ahvenainen, R., Ed.; Woodhead Publishing Ltd.: Cambridge, MA, USA, 2003; pp. 127-143.

125. Taoukis, P.; Tsironi, T. Smart Packaging for Monitoring and Managing Food and Beverage Shelf Life. In Food and Beverage Stability and Shelf Life; Kilcast, D., Subramaniam, P., Eds.; Woodhead Publishing Limited: Cambridge, UK, 2016; Chapter 5; pp. 141-168.

126. Janjarasskul, T.; Suppakul, P. Active and intelligent packaging: The indication of quality and safety. Crit. Rev. Food Sci. Nutr. 2018, 58, 808-831. [CrossRef] [PubMed] 
127. EU. Guidance to the Commission Regulation (EC) No 450/2009 of 29 May 2009 on Active and Intelligent Materials and Articles Intended to Come into Contact with Food. In Version 10. European Commission Health and Consumers Directorate-General Directorate E-Safety of the Food Chain. E6-Innovation and Sustainability. 2009. Available online: https:/ / eur-lex.europa.eu/ legal-content/en/LSU/?uri=CELEX\%3A32009R0450 (accessed on 19 February 2021).

128. Fellows, P.J. Packaging. In Food Processing Technology. Principles and Practice, 4th ed.; Woodhead Publishing: Duxford, UK, 2016; Chapter 24; pp. 949-1044.

129. Tsironi, T.; Taoukis, P. Current practice and innovations in fish packaging. J. Aquat. Food Prod. Technol. 2018, $27,1024-1047$. [CrossRef]

130. Lagaron, J.M.; Catala, R.; Gavara, R. Structural characteristics defining high barrier properties in polymeric materials. Mater. Sci. Technol. 2004, 20, 1-7. [CrossRef]

131. Teixeira, V.; Carneiro, J.; Carvalho, P.; Silva, E.; Azevedo, S.; Batista, C. High barrier plastics using nanoscale inorganic films. In Multifunctional and Nanoreinforced Polymers for Food Packaging; Lagarón, J.M., Ed.; Woodhead Publishing: Cambridge, UK, 2011; pp. 285-315.

132. Day, B.P.F. Extension of shelf-life of chilled foods. Eur. Food Drink Rev. 1989, 4, 47-56.

133. Day, B.P.F. Active packaging-A fresh approach. Brand $\odot$ J. Brand Technol. 2001, 1, 32-41.

134. Rooney, M.L. Active Food Packaging; Chapman \& Hall: London, UK, 1995.

135. Bodbodak, S.; Rafiee, Z. Recent trends in active packaging in fruits and vegetables. In Eco-Friendly Technology for Postharvest Produce Quality; Siddiqui, M.W., Ed.; Academic Press Inc.: Cambridge, MA, USA, 2016; pp. 77-125.

136. Idol, R. Oxygen scavenging: Top marks. Packag. Week 1993, 9, 17-19.

137. Cichello, S.A. Oxygen absorbers in food preservation: A review. J. Food Sci. Technol. 2015, 52, 1889-1895. [CrossRef]

138. Charles, F.; Sanchez, J.; Gontard, N. Active modified atmosphere packaging of fresh fruits and vegetables: Modeling with tomatoes and oxygen absorber. J. Food Sci. 2003, 68, 1736-1742. [CrossRef]

139. Emenhiser, C.; Watkins, R.H.; Simunovic, N.; Solomons, N.; Bulux, J.; Barrows, J.; Schwartz, S.J. Packaging preservation of $\beta$-Carotene in sweet potato flakes using flexible film and an oxygen absorber. J. Food Qual. 1999, 22, 63-73. [CrossRef]

140. Tarr, C.R.; Clingeleffer, P.R. Use of an oxygen absorber for disinfestation of consumer packages of dried vine fruit and its effect on fruit colour. J. Stored Prod. Res. 2005, 41,77-89. [CrossRef]

141. Alzamora, S.M.; Guerrero, S.; López-Malo, A.; Palou, E. Plant antimicrobials combined with conventional preservatives for fruit products. In Natural Antimicrobials for the Minimal Processing of Foods; Roller, S., Ed.; Woodhead Publishing: London, UK, $2003 ;$ pp. $235-249$.

142. Ganiari, S.; Choulitoudi, E.; Oreopoulou, V. Edible and active films and coatings as carriers of natural antioxidants for lipid food. Trends Food Sci. Technol. 2017, 68, 70-82. [CrossRef]

143. Dongen, W.D.V.; Kruijf, N.D. Intelligent and Active Packaging for Fruits and Vegetables; CRC Press: Boca Raton, FL, USA, 2007.

144. Romanazzi, G.; Feliziani, E.; Santini, M.; Landi, L. Effectiveness of postharvest treatment with chitosan and other resistance inducers in the control of storage decay of strawberry. Postharvest Biol. Technol. 2013, 75, 24-27. [CrossRef]

145. Choulitoudi, E.; Velliopoulou, A.; Tsimogiannis, D.; Oreopoulou, V. Effect of active packaging with Satureja thymbra extracts on the oxidative stability of fried potato chips. Food Packag. Shelf Life 2020, 23, 100455. [CrossRef]

146. Cordeiro de Azeredo, H.M. Edible coatings. In Advances in Fruit Processing Technologies; Rodrigues, S., Fernandes, F.A.N., Eds.; CRC Press Inc.: Boca Raton, FL, USA, 2012; pp. 345-361.

147. Dhall, R.K. Advances in edible coatings for fresh fruits and vegetables: A review. Crit. Rev. Food Sci. Nutr. 2012, 53, 435-450. [CrossRef]

148. Lin, D.; Zhao, Y. Innovations in the development and application of edible coatings for fresh and minimally processed fruits and vegetables. Compr. Rev. Food Sci. Food Saf. 2007, 6, 60-75. [CrossRef]

149. Smolander, M. Freshness indicators and food packaging. In Smart Packaging Technologies for Fast Moving Consumer Goods; Kerry, J., Butler, P., Eds.; John Wiley \& Sons Ltd.: West Sussex, UK, 2008; pp. 111-127.

150. Vanderroost, M.; Ragaert, P.; Devlieghere, F.; De Meulenaer, B. Intelligent food packaging: The next generation. Trends Food Sci. Technol. 2014, 39, 47-62. [CrossRef]

151. Rhim, J.W.; Kim, Y.T. Biopolymer-based composite packaging materials with Nanoparticles. In Innovations in Food Packaging, 2nd ed.; Han, J.H., Ed.; Elsevier Ltd.: London, UK, 2014; pp. 413-442.

152. Kuswandi, B. Freshness Sensors for Food Packaging. Ref. Modul. Food Sci. 2017, 1-11. [CrossRef]

153. Gómez, A.H.; Hu, G.; Wang, J.; Pereira, A.G. Evaluation of tomato maturity by electronic nose. Comput. Electron. Agric. 2006, 54, 44-52. [CrossRef]

154. Kuswandi, B.; Maryska, C.; Abdullah, A.; Heng, L.Y. Real time on-package freshness indicator for guavas packaging. J. Food Meas. Charact. 2013, 7, 29-39. [CrossRef]

155. Taoukis, P.S.; Labuza, T.P. Applicability of time temperature indicators as shelf life monitors of food products. J. Food Sci. 1989, 54, 783-788. [CrossRef]

156. Taoukis, P.S. Commercialization of time-temperature integrators for foods. In Case Studies in Novel Food Processing Technologies: Innovations in Processing, Packaging and Predictive Modelling; Doona, C.J., Kustin, K., Feeherry, F.E., Eds.; Woodhead Publishing Limited: Cambridge, UK, 2010; Chapter 14; pp. 351-365.

157. Bobelyn, E.; Hertog, M.L.A.T.M.; Nicolaï, B.M. Applicability of an enzymatic time temperature integrator as a quality indicator for mushrooms in the distribution chain. Postharvest Biol. Technol. 2006, 42, 104-114. [CrossRef] 